\title{
SUMMARY OF LITHOLOGIC LOGGING OF NEW AND EXISTING BOREHOLES AT YUCCA MOUNTAIN, NEVADA, AUGUST 1993 TO FEBRUARY 1994
}

\author{
by Jeffrey K. Geslin, Thomas C. Moyer, and David C. Buesch
}

\section{U.S. GEOLOGICAL SURVEY}

Open-File Report 94-342

Prepared in cooperation with the NEVADA OPERATIONS OFFICE, U.S. DEPARTMENT OF ENERGY under Interagency Agreement DE-Al08-92NV10874

\section{DISCLAIMER}

This report was prepared as an account of work sponsored by an agency of the United States Government. Neither the United States Government nor any agency thereof, nor any of their employees, makes any warranty, express or implied, or assumes any legal liability or responsibility for the accuracy, completeness, or usefulness of any information, apparatus, product, or process disclosed, or represents that its use would not infringe privately owned rights. Reference herein to any specific commercial product, process, or service by trade name, trademark, manufacturer, or otherwise does not necessarily constitute or imply its endorsement, recommendation, or favoring by the United States Government or any agency thereof. The views and opinions of authors expressed herein do not necessarily state or reflect those of the United States Government or any agency thereof.

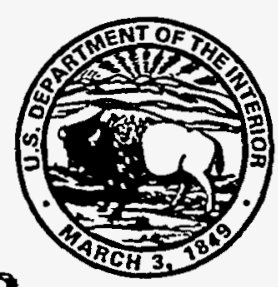




\title{
U.S. DEPARTMENT OF THE INTERIOR BRUCE BABBITT, Secretary
}

\author{
U.S. GEOLOGICAL SURVEY
}

Gordon P. Eaton, Director

The use of trade, product, industry, or firm names is for descriptive purposes only and does not imply endorsement by the U.S. Government.

For additional information write to: Chief, Earth Science Investigations Program Yucca Mountain Project Branch U.S. Geological Survey Box 25046, MS 421 Denver Federal Center Denver, CO 80225
Copies of this report can be purchased from: U.S. Geological Survey Earth Science Information Center Open-File Reports Section Box 25286, MS 517 Denver Federal Center Denver, CO 80225 


\section{DISCLAIMER}

Portions of this document may be illegible in electronic image products. Images are produced from the best available original document. 


\section{CONTENTS}

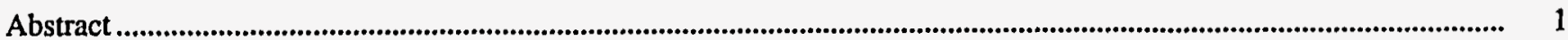

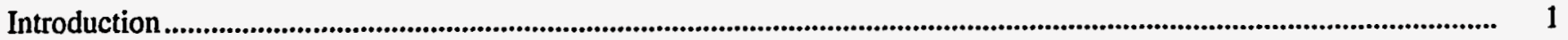

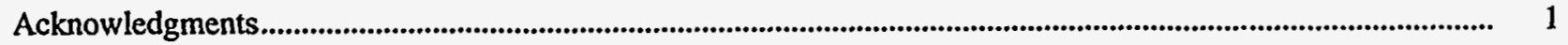

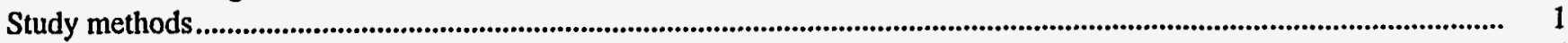

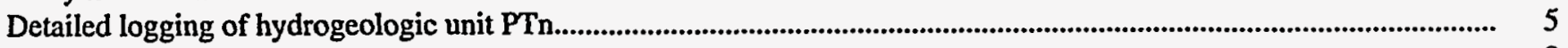

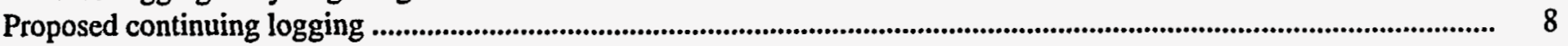

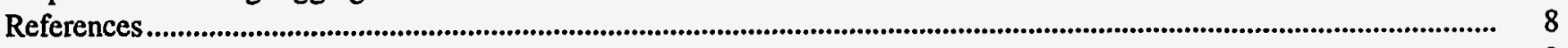

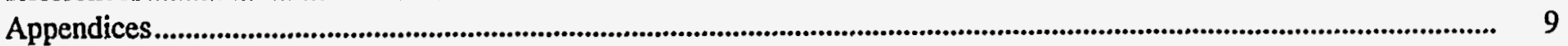

Appendix 1. Criteria for contact selection in boreholes at Yucca Mountain, Nevada ................................................... 10

Appendix 2. Tables of lithologic contacts in boreholes at Yucca Mountain, Nevada................................................... 15

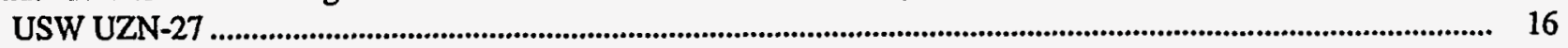

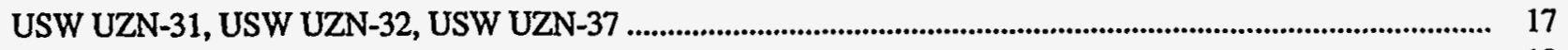

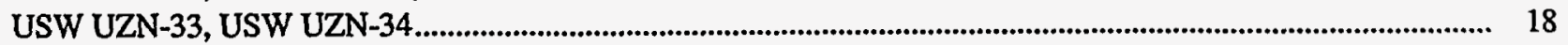

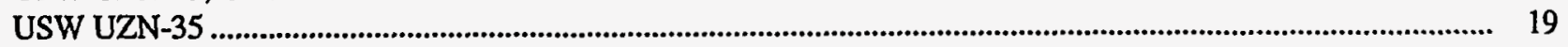

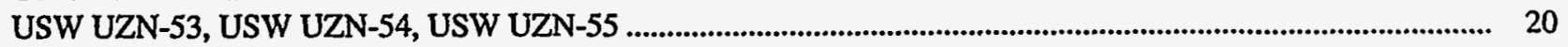

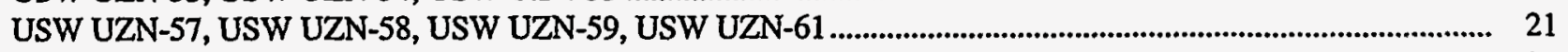

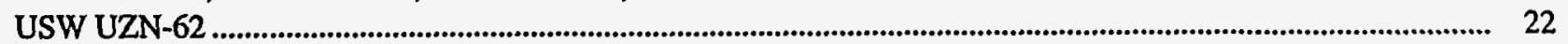

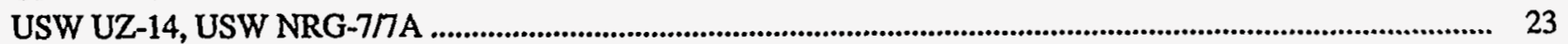

Appendix 3. Graphical lithologic logs for boreholes at Yucca Mountain, Nevada ........................................................ 25

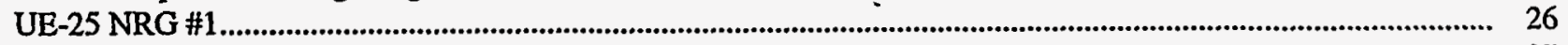

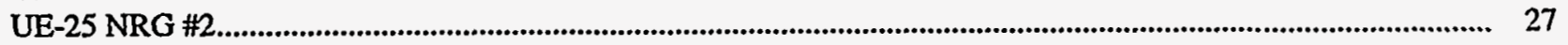

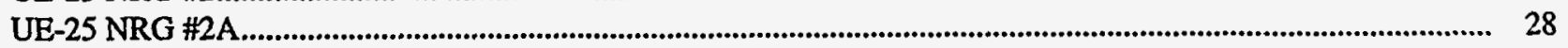

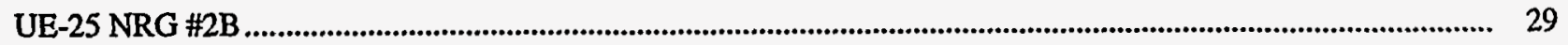

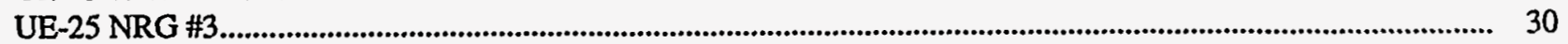

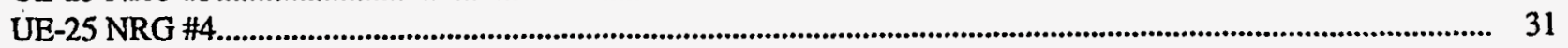

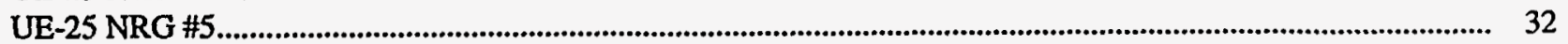

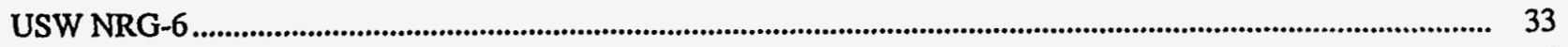

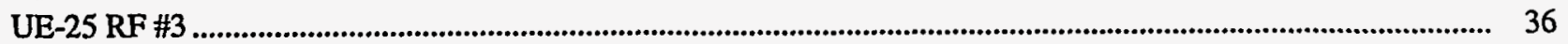

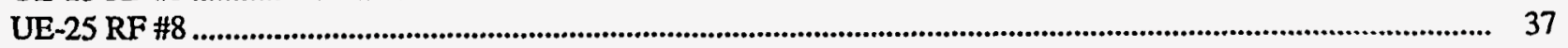

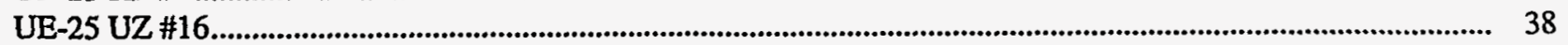

\section{FIGURE}

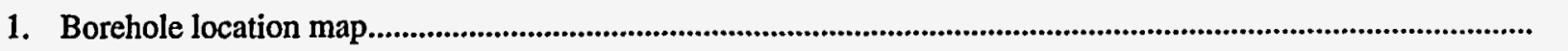

\section{TABLES}

1. Location and information on boreholes logged at Yucca Mountain, August 1993 to February 1994 .....................

2. Lithostratigraphic nomenclature of the Paintbrush Group at Yuccá Mountain, Nevada ........................................

3. Generalized lithostratigraphy of boreholes at Yucca Mountain, Nevada............................................................ 
CONVERSION FACTORS AND VERTICAL DATUM

\begin{tabular}{rll}
\hline Multiply & By & To obtain \\
\hline & & inch \\
millimeter $(\mathrm{mm})$ & 0.03937 & inch \\
centimeter $(\mathrm{cm})$ & 0.3937 & foot \\
meter $(\mathrm{m})$ & 3.281 & mile \\
\hline
\end{tabular}

Sea level: In this report "sea level" refers to the National Geodetic Vertical Datum of 1929 (NGVD of 1929)-a geodetic datum derived from a general adjustment of the first-order level nets of both the United States and Canada, formerly called Sea Level Datum of 1929. 


\title{
Summary of Lithologic Logging of New and Existing Boreholes at Yucca Mountain, Nevada, August 1993 to February 1994
}

\author{
By'Jeffrey K. Geslin, Thomas C. Moyer, and David C. Buesch
}

\begin{abstract}
This report summarizes lithologic logging of core from boreholes at Yucca Mountain, Nevada, conducted from August 1993 to February 1994. Units encountered during logging include Quaternary-Tertiary alluvium/colluvium, Tertiary Rainier Mesa Tuff, all units in the Tertiary Paintbrush Group, Tertiary Calico Hills Formation, and Tertiary Prow Pass Tuff. We present criteria used for recognition of stratigraphic contacts, logging results as tables of contact depths for core from neutron (UZN) boreholes and graphical lithologic logs for core from non-UZN boreholes, and descriptions of several distinctive nonwelded tuffs recognized in the PTn hydrogeologic unit of the Paintbrush Group.
\end{abstract}

\section{INTRODUCTION}

Yucca Mountain, Nevada, is being investigated as a potential site for a high-level radioactive waste repository. This report summarizes the lithologic logging of new and existing boreholes at Yucca Mountain that was done from August 1993 to February 1994 by the Rock Characteristics Section, Yucca Mountain Project Branch, U.S. Geological Survey (USGS). This logging was done under Study Plan 8.3.1.4.2.1.1, and the study-level objective was to determine the spatial distribution and characteristics of stratigraphic units within the Yucca Mountain site area. Stratigraphic data obtained from lithologic logging are used in the threedimensional lithostratigraphic model of Yucca Mountain being developed by the Rock Characteristics Section. These data also can be integrated into hydrologic studies at Yucca Mountain and applied to engineering and construction of the Exploratory Studies Facility.

Lithostratigraphic units identified during logging include Quaternary-Tertiary alluvium/colluvium, the Tertiary Rainier Mesa Tuff of the Timber Mountain Group, all units in the Tertiary Paintbrush Group, the Tertiary Calico Hills Tuff, and the Tertiary Prow Pass Tuff of the Crater Flat Group. Stratigraphic nomencla- ture and lithologic descriptions of stratigraphic units in the Tiva Canyon, Yucca Mountain, Pah Canyon, and Topopah Spring Tuffs of the Paintbrush Group are from Sawyer and others (in press) and also are summarized in D.C. Buesch and others (USGS, written commun., 1994). Interstratified, nonwelded volcaniclastic and epiclastic deposits in the Paintbrush Group also were logged, and several distinctive units are described in this report.

The boreholes logged from August 1993 to February 1994 are listed, with their location and collar elevation, in table 1. Table 1 also lists the Data Tracking Number (DTN) for stratigraphic data from each borehole that have been released to the Yucca Mountain Project and that are stored in the USGS Local Records Center in Denver, Colorado. The locations of these boreholes are shown in figure 1. Cores from boreholes logged during this study are stored at the Yucca Mountain Project Sample Management Facility at the Nevada Test Site.

\section{Acknowledgments}

The lithostratigraphy used during this logging was developed with the aid of R. Spengler (USGS).

\section{STUDY METHODS}

Lithostratigraphic units identified in core follow the stratigraphic hierarchy and nomenclature for the Paintbrush Group defined in Sawyer and others (in press) and followed by D.C. Buesch and others (USGS, written commun., 1994) (table 2). The criteria used to identify contacts between stratigraphic units are shown in appendix 1. Lithologic logging includes either identification of the depths of stratigraphic contacts (herein referred to as type 1 logging) or identification of the depths of contacts and detailed unit descriptions (herein referred to as type 2 logging). The results of type 1 logging are reported as tables of contact depths (appendix 2), whereas the results of type 2 logging are reported in graphical form (appendix 3). Both types of logs are submitted to the USGS Yucca 
Table 1. Location and information on boreholes logged at Yucca Mountain, August 1993 to February 1994

[Northing, easting, and collar elevation data are from Reynolds Electrical and Engineering Company and were provided as information to the Yucca Mountain Project. * indicates predrilling locations and elevations and are subject to change. Northing and easting are based on the Nevada State Coordinate System. Locations and elevations are in feet.]

\begin{tabular}{|c|c|c|c|c|}
\hline $\begin{array}{l}\text { Borehole } \\
\text { number }\end{array}$ & Northing & Easting & Collar elevation & Data tracking number \\
\hline \multicolumn{5}{|c|}{ Identification of lithologic contacts (type 1 logging) } \\
\hline USW UZ-N27 & $771,569.7$ & $558,821.9$ & $4,859.5$ & GS940208314211.004 \\
\hline USW UZ-N31 & $764,245.7$ & $562,751.9$ & $4,101.0$ & GS940208314211.005 \\
\hline USW UZ-N32 & $764,302.6$ & $562,799.6$ & $4,156.2$ & GS940208314211.005 \\
\hline USW UZ-N33 & $769,760.1$ & $561,239.0$ & $4,331.1$ & GS940208314211.006 \\
\hline USW UZ-N34 & $770,158.7$ & $561,251.5$ & $4,324.2$ & GS940208314211.006 \\
\hline USW UZ-N35 & $762,263.8$ & $562,310.0$ & $4,247.4$ & GS940208314211.007 \\
\hline USW UZ-N37 & $767,499.1$ & $563,713.5$ & $4,123.6$ & GS940208314211.005 \\
\hline USW UZ-N53 & $760,095.9$ & $564,236.9$ & $4,055.6$ & GS940208314211.003 \\
\hline USW UZ-N54 & $760,272.0$ & $564,262.2$ & $4,045.9$ & GS940208314211.003 \\
\hline USW UZ-N55 & $760,502.9$ & $564,248.3$ & $4,072.6$ & GS940208314211.003 \\
\hline USW UZ-N57 & $755,164.5$ & $560,829.9$ & $4,183.6$ & GS940208314211.008 \\
\hline USW UZ-N58 & $755,240.4$ & $560,862.2$ & $4,179.2$ & GS940208314211.008 \\
\hline USW UZ-N59 & $755,321.3$ & $560,888.4$ & $4,177.7$ & GS940208314211.008 \\
\hline USW UZ-N61 & $755,375.9$ & $560,894.0$ & $4,182.1$ & GS940208314211.008 \\
\hline USW UZ-N62 & $757,125.2$ & $558,302.7$ & $4,875.5$ & GS940208314211.002 \\
\hline USW NRG-7/7a & $768,880^{*}$ & $562,984^{* *}$ & $4,207 *$ & GS940108314211.001 \\
\hline USW UZ-14 & $771,309 *$ & $560,141^{*}$ & $4,425^{*}$ & GS940108314211.001 \\
\hline \multicolumn{5}{|c|}{ Detailed lithologic logging (type 2 logging) } \\
\hline UE-25 NRG \#1 & $765,358.6$ & $569,803.1$ & $3,754.6$ & GS931208314211.046 \\
\hline UE-25 NRG \#2 & $765,763.8$ & $569,164.4$ & $3,796.7$ & GS931008314211.039 \\
\hline UE-25 NRG \#2a & $765,699.9$ & $569,001.1$ & $3,780.6$ & GS931008314211.038 \\
\hline UE-25 NRG \#2b & $765,765.2$ & $569,214.5$ & $3,801.4$ & GS931108314211.041 \\
\hline UE-25 NRG \#3 & $766,250.6$ & $568,316.1$ & $3,823.3$ & GS931008314211.037 \\
\hline UE-25 NRG \#4 & $767,080.2$ & $566,820.0$ & $4,099.7$ & GS931108314211.042 \\
\hline UE-25 NRG \#5 & $767,889.6$ & $564,769.9$ & $4,106.7$ & GS931108314211.043 \\
\hline USW NRG-6 & $766,726.3$ & $564,187.2$ & $4,092.2$ & GS931008314211.045 \\
\hline UE-25 RF \#3 & $765,575.1$ & $571,100.1$ & $3,657.8$ & GS931008314211.036 \\
\hline UE-25 RF \#8 & $765,630.8$ & $568,789.9$ & $3,787.9$ & GS931008314211.035 \\
\hline UE-25 UZ\#16 & $760,535.2$ & $564,857.5$ & $4,000.6$ & GS931208314211.047 \\
\hline
\end{tabular}




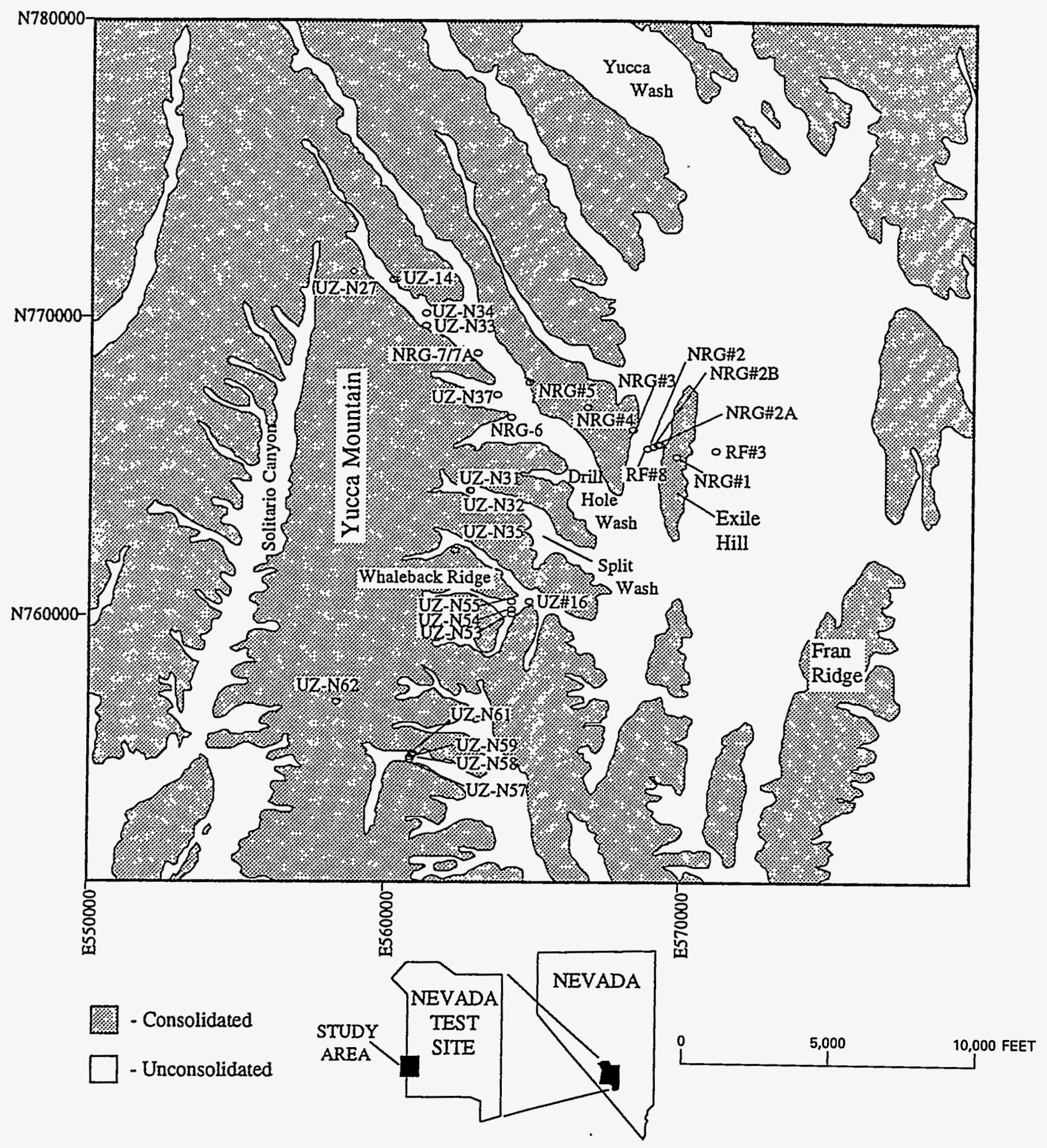

Figure 1. Borehole location map (modified from Nelson and others, 1991). 
Table 2. Lithostratigraphic nomenclature of the Paintbrush Group at Yucca Mountain, Nevada (from Sawyer and others, in press; D.C. Buesch and others, written commun.)

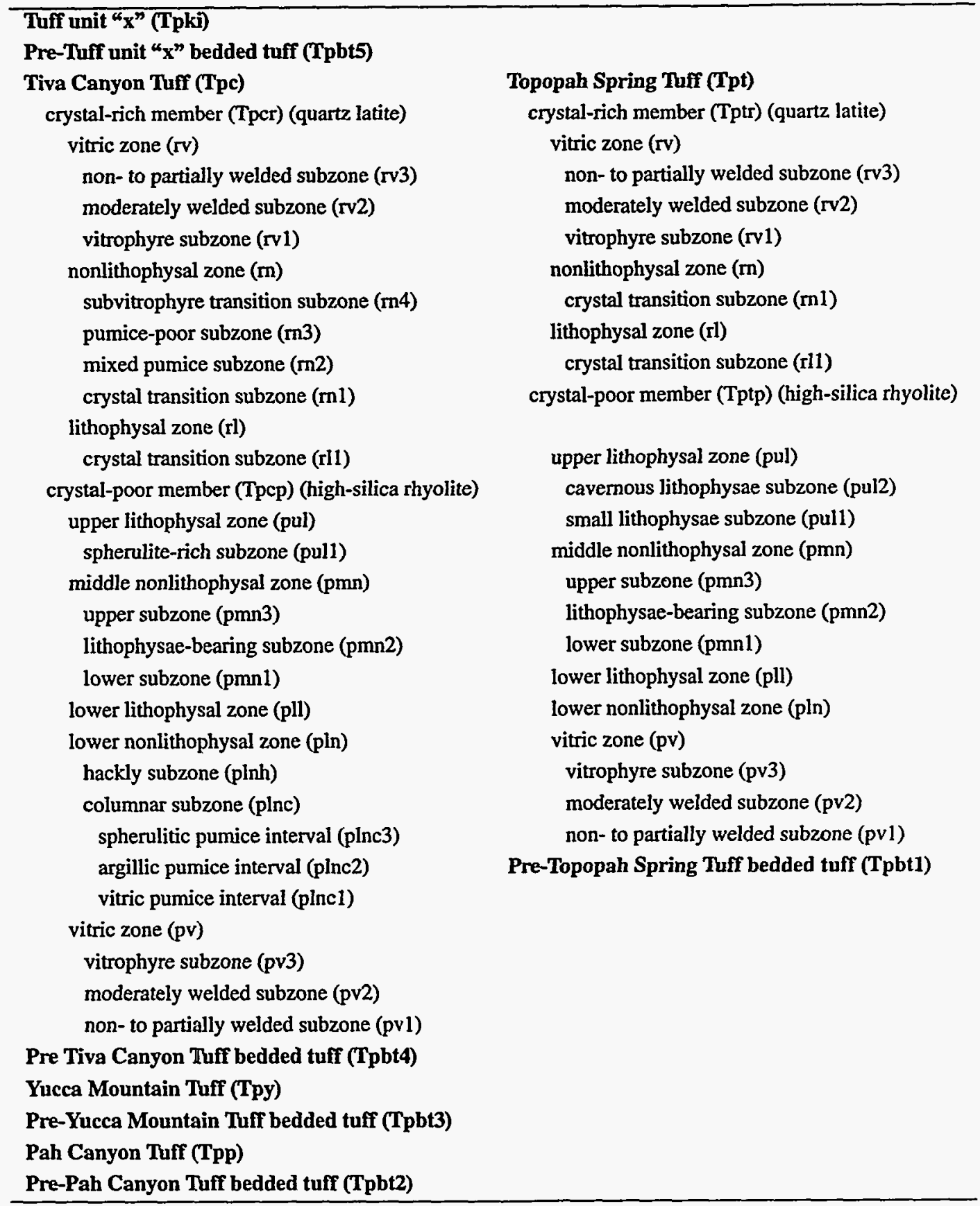


Mountain Project Branch Local Records Center in Denver, Colorado, following internal review. The lithostratigraphic units encountered during type 1 and type 2 logging of core from boreholes are summarized in table 3.

Type 1 logs (appendix 2) were completed for core recovered from unsaturated zone neutron (UZN series) boreholes, for core recovered from borehole NRG-7/7A from the surface to a depth of 990 feet, and for borehole UZ-14 from the surface to a depth of 1435 feet. Future work will include type 2 logging of boreholes NRG-7/7A and UZ-14. Core recovered from UZN-series boreholes is stored in lexan tubing that limits viewing of the core and modifies colors by retaining moisture. Contacts that are difficult to identify through lexan or that were removed by sampling were confirmed or constrained by examination of processed samples at the Hydrologic Research Facility or by viewing videotapes of core photographed prior to sample removal.

Type 2 lithologic logs (appendix 3) were created for core recovered from non-UZN-series boreholes. These logs use the criteria of D.C. Buesch and others (USGS, written commun., 1994) to identify the welding and crystallization zones in each unit. Accompanying lithologic unit descriptions include the phenocryst content and assemblage; lithophysae content and size; pumice content, size, and composition; lithic clast content, size and composition; and matrix color and content. The percentage of phenocrysts, lithic clasts, pumice clasts and lithophysae are visually estimated using charts included in the Munsell Soil Color Charts (Kollmorgen Instruments Corp., 1992). Phenocryst, pumice, and lithic clast types are identified with the aid of a hand lens or binocular microscope. The maximum and minimum dimensions of pumice, lithic clast, and lithophysae (void) sizes are measured along two perpendicular axes and recorded as either typical or maximum sizes observed. Pumice, lithic clast, and matrix colors are determined on dry core using Munsell Color Charts (Geological Society of America, 1991;

Kollmorgen Instruments Corp., 1992). Other features of the core, including fracture geometry and morphology, fracture mineralization, and development and orientation of foliation (dip angle measured from horizontal), also are recorded and included in unit descriptions.

\section{DETAILED LOGGING OF HYDROGEOLOGIC UNIT PTn}

In the course of logging clusters of UZN-series boreholes, it was recognized that beds within the Paintbrush Tuff nonwelded (PTn) hydrogeologic unit (including the moderately to nonwelded base of the Tiva Canyon Tuff (subzones Tpcpv2 and pv1), Yucca Mountain Tuff, Pah Canyon Tuff, the upper nonwelded to moderately welded portion of the Topopah Spring Tuff (subzones Tptrv3 and rv2), and interbedded nonwelded tuffaceous rocks) could be correlated throughout portions of Yucca Mountain. These units are not described or defined in D.C. Buesch and others (written commun.). Preliminary lithologic logging indicates . that these units may be laterally continuous and that the number of beds and their composite thickness increase northward. Continued detailed logging of PTn could provide a basis for correlation in regions where Paintbrush formations (for example, Pah Canyon Tuff) are absent, and will help to define a stratigraphic architecture to guide three-dimensional hydrologic models. Below are outlined the criteria used to distinguish several key units recognized to date.

Pre-Pah Canyon (Tpbt2): The Pah Canyon Tuff rests on an interval of light brown, possibly reworked, tuffaceous material that contains distinctive clasts of porphyritic obsidian, light gray microvesicular pumice, and small pink pumice clasts. This unit has been recognized in boreholes at the east end of Whaleback Ridge (for example, UZ-N53 and UZ \#16) and throughout Drill Hole Wash (for example, NRG-6 and UZ-14).

Post-Pah Canyon (Tpbt3): Overlying the Pah Canyon Tuff is an interval that grades abruptly upward from clast-supported pumice to matrix-supported pumice. This unit has been observed in boreholes at the east end of Whaleback Ridge (for example, UZ-N53 and UZ\#16) and throughout Drill Hole Wash (for example, NRG-6, NRG-7/7A, and UZ-14).

Pre-Yucca Mountain (Tpbt3): Interbedded with a stratigraphically complex sequence of nonwelded deposits that underlies the Yucca Mountain Tuff is a distinctive pumice- and lithic-rich fallout deposit. This unit has been identified in boreholes at the east end of Whaleback Ridge (for example, UZ-N53 and UZ \#16), in Split Wash (for example, UZ-N32), and throughout Drill Hole Wash (for example, NRG-6, NRG-7/7A, and UZ-14). Broxton and others (1993) related this sequence of deposits to eruptions of rhyolite lava north of Yucca Wash (Delirium Canyon and Black Glass Canyon).

Post-Yucca Mountain (Tpbt4): Overlying the Yucca Mountain Tuff is a sandy, possibly reworked, tuffaceous deposit that contains angular fragments of obsidian. This discontinuous unit has been recognized in borehole UZ \#16, in boreholes in Split Wash (for example, UZ-N32), and in boreholes throughout Drill Hole Wash (for example, NRG-6 and NRG-7/7A). 
Table 3. Generalized lithostratigraphy of boreholes at Yucca Mountain, Nevada

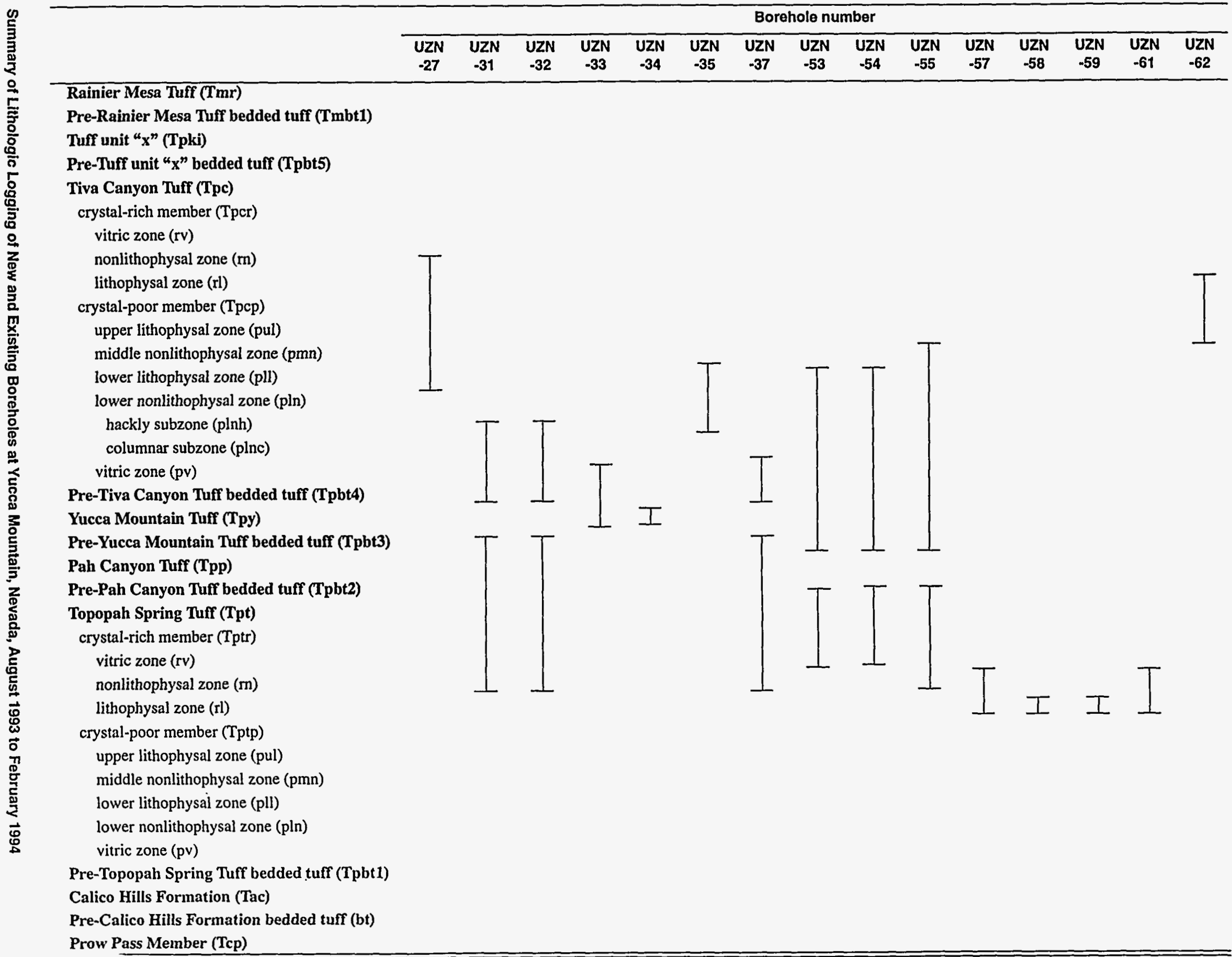


Table 3. Generalized lithostratigraphy of boreholes at Yucca Mountain, Nevada-Continued

Borehole number

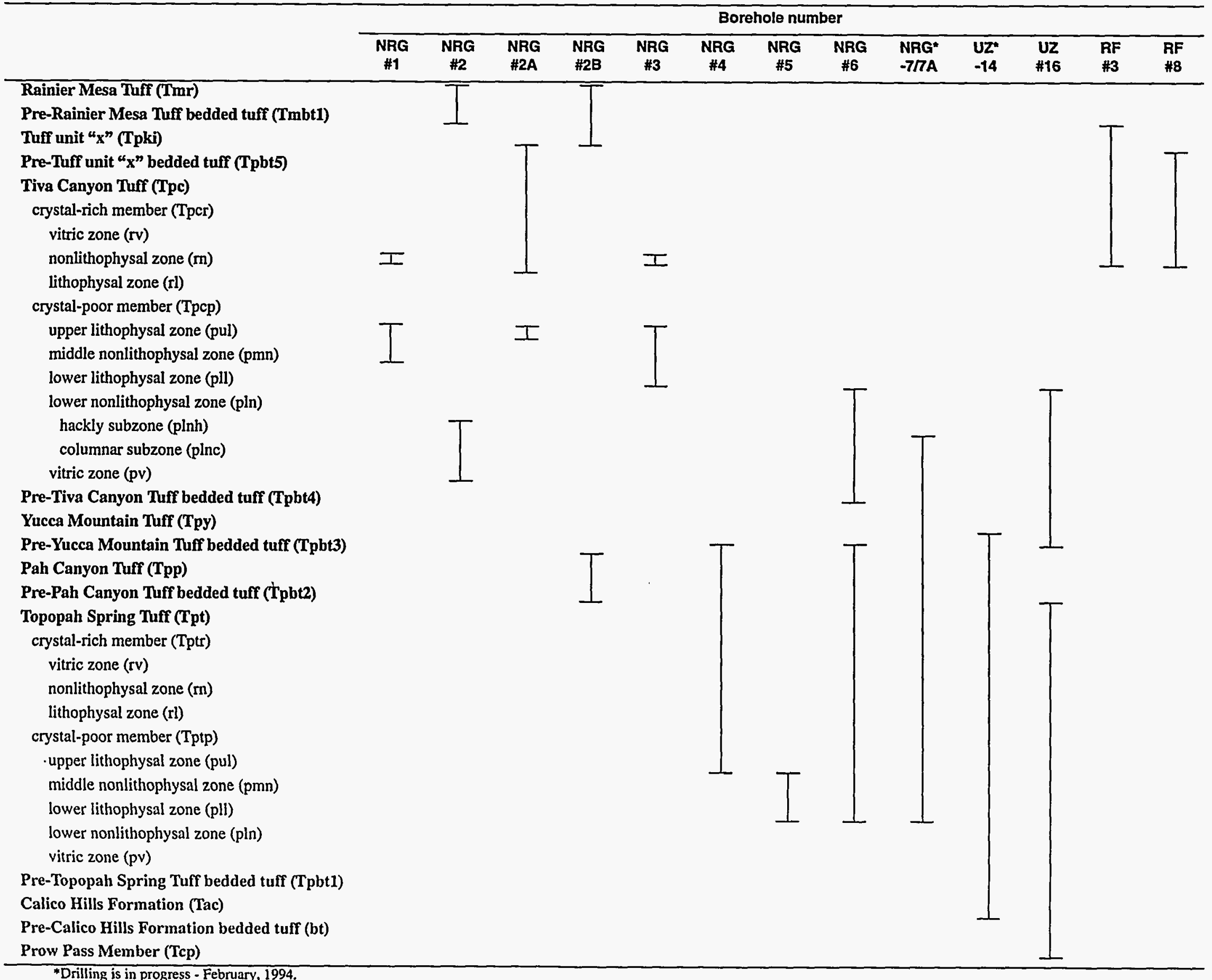

"Drilling is in progress - February, 1994. 


\section{PROPOSED CONTINUING LOGGING}

Logging proposed for 1994 and 1995 will produce a table of contact depths for boreholes NRG-7/7A, NRG \#5A, SD-9, SD-10, SD-12, UZ-7A, SRG-1, SRG-2, SRG-3, and SRG-4 (depending on drilling progress), that will be submitted to the USGS Yucca Mountain Project Branch Local Records Center upon completion of drilling and following internal review. Graphical lithologic logs that summarize detailed logging will be prepared for NRG-7/7A, SD-9, SD-12, and UZ-7A (depending on drilling progress). These data will be integrated into the threedimensional lithostratigraphic model of Yucca Mountain being constructed by the Rock Characteristics Section, USGS.

\section{REFERENCES}

Broxton, D.E., Chipera, S.J., Byers, F.M., Jr., and Rautman, C.A., 1993, Geologic evaluation of six nonwelded tuff sites in the vicinity of Yucca Mountain, Nevada, for a surface-based test facility for the Yucca Mountain Project: Los Alamos National Laboratory Report LA-12542-MS, 83 p. (NNA.930826.0064)
Geological Society of America, 1991, Rock-color chart: Boulder, Colo., Geologic Society of America. (MOL.19940810.0002)

Kollmorgen Instruments Corporation, 1992, Munsell soil color charts: New York, Kollmorgen Instruments Corporation. (MOL.19940810.0003)

Nelson, P.H., Muller, D.C., Schimschal, U., and Kibler, J.E., 1991, Geophysical logs and core measurements from forty boreholes at Yucca Mountain, Nevada: U.S. Geological Survey, Geophysical Investigations Map GP-1001, 64 p. (NNA.920211.0022)

Sawyer, D.A., Fleck, R.J., Lanphere, M.A., Warren, R.G., Broxton, D.E., and Hudson, M.R., Episodic caldera volcanism in the Miocene southwestern Nevada volcanic field: Revised stratigraphic framework, ${ }^{40} \mathrm{Ar} /{ }^{39} \mathrm{Ar}$ geochronology, and implications for magmatism and extension: Geological Society of America Bulletin, in press. (MOL.19940725.0004)

NOTE: Parenthesized numbers following each cited reference are for U.S. Department of Energy OCRWM Records Management purposes only and should not be used when ordering the publication. 


\section{APPENDICES 1-3}

$\frac{i}{3}$ 


\section{APPENDIX 1. CRITERIA FOR CONTACT SELECTION IN BOREHOLES AT YUCCA MOUNTAIN, NEVADA}

Described below are the defining criteria that distinguish the basal contacts of the lithostratigraphic units identified in the boreholes shown in table 1, appendix 2 , and appendix 3 , with the units arranged from youngest to oldest. Because this appendix does not provide comprehensive unit descriptions, readers unfamiliar with local stratigraphic relations may find it helpful to proceed stratigraphically upward from the base of the Calico Hills Formation. Descriptions of most of the units may be found in "Summary Lithologic Descriptions of the Upper Tiva Canyon Formation and Tuff Unit " $x$ " in the North Ramp Area" written by T. Moyer, J. Geslin, and D. Buesch (DTN: GS931108314211.044) and D.C. Buesch and others (written commun.). Unit designations follow D.C. Buesch and others (written commun.).

\section{Alluvium/Colluvium (QTac)}

A sharp depositional contact identified as the point above which the core consists of polylithologic clasts, often coated with caliche, in a sandy matrix. Core recovery is typically poor.

\section{Rainier Mesa Tuff (Tmr)}

A sharp depositional contact above which is a basal, nonlithified, clast-supported fallout deposit that contains pumice lapilli and about 20 volume percent crystals, including vitreous quartz. The fallout deposit is overlain by the Rainier Mesa pyroclastic-flow deposit that is pale yellowish-brown to pinkish-white and contains distinctive clear bubble-wall glass shards and about 20 volume percent crystals, including vitreous quartz.

\section{Pre-Rainier Mesa bedded tuff (Tmbt1)}

A sharp depositional contact above which is a pinkish-gray pyroclastic-flow deposit (in NRG\#2B) or a muddy, fine-grained, poorly sorted, cross-bedded, volcaniclastic sandstone and reworked pyroclastic-fiow deposit (in RF \#3).

\section{Tuff Unit "x" (Tpki)}

A sharp depositional contact above which is a basal, well-sorted, clast-supported lapilli fallout deposit, overlain by the pyroclastic-flow deposit of tuff unit " $x$ " that is very light gray, lithic-rich, and commonly contains altered pumice clasts.

\section{Pre-Tuff Unit “ $x$ " bedded tuff (Tpbt5)}

A sharp depositional contact above which is a pinkish-gray to grayish-orange, cross-bedded (in RF\#3), reworked, pyroclastic-flow deposit.

\section{Tiva Canyon Tuff (Tpc)}

\section{crystal-rich vitric zone (Tpcrv)}

non- to partially welded subzone (rv3) - A gradational contact identified as the discrete interval above which pumice clasts are not deformed, matrix foliation is weak to absent, the rock breaks along grain boundaries, and the vitroclastic matrix has macroscopic porosity.

moderately welded subzone (rv2) - A generally sharp contact identified as the point above which pumice clasts retain macroscopic porosity despite strong deformation, and in which the rock breaks across the vitroclastic texture. Macroscopic matrix porosity is generally absent.

vitrophyre subzone (rv1) - A sharp contact identified as the point above which the rock is a densely fused mass with a glassy matrix that lacks vitroclastic texture (pumice clasts locally are devitrified).

crystal-rich nonlithophysal zone (Tpcrn)

subvitrophyre transition subzone ( $\mathrm{rn} 4)$ - A sharp contact, locally depositional, identified as the point above which pumice clasts comprise more than 5 volume percent of the rock by visual estimate. Pumice clasts are typically altered to clay above this point but locally are vapor-phase-altered and corroded.

pumice-poor subzone (rn3) - A gradational contact identified as the interval above which pum- 
ice clasts comprise less than 5 volume percent of the rock by visual estimate. The contact is locally expressed as a sharp color change from reddish-brown above to dark reddish-gray below.

mixed pumice subzone (rn2) - A sharp to gradational contact identified as the point or interval above which the phenocryst content of the matrix exceeds 10 to 12 volume percent of the rock by visual estimate and above which lithophysal cavities are absent. Pumice clasts commonly comprise more than 10 volume percent above the contact. The contact with subzone $\mathrm{r} 12$ is marked by the absence of lithophysal cavities and an increase in the percentage of recovered core above the contact.

crystal transition subzone.(m1) - A gradational contact identified as the interval above which the phenocryst content of the matrix increases upward from approximately 5 volume percent by visual estimate, with oxidized (bronzecolored) biotite and pyroxene pseudomorphs present. Phenocryst content is less than 5 volume percent below the contact. The contact with zone pul or subzone rll is marked by the absence of lithophysal cavities and an increase in the percentage of recovered core above the contact. The unit occurs only where subzone r12 is absent.

\section{crystal-rich lithophysal zone (Tpcrl)}

lithophysal subzone (r12) - A gradational contact identified as the interval above which phenocryst content exceeds 10 to 12 volume percent of the rock by visual estimate. The rock matrix above the contact typically has less vaporphase alteration than below.

crystal transition subzone (rl1) - A gradational contact identified as the interval above which the phenocryst content of the matrix increases upward from approximately 5 volume percent by visual estimate, with oxidized (bronzecolored) biotite and pyroxene pseudomorphs present. Phenocryst content is less than 5 volume percent below the contact.

crystal-poor upper lithophysal zone (Tpcpul)

Contact with middle nonlithophysal zone is gradational and identified as the interval above which the rock contains lithophysal cavities, has a grayish-red-purple matrix that is variably altered to vapor-phase minerals, and that fractures in an irregular manner. The contact with subzone pul1 is sharp and identified as the point above which lithophysal cavities occur; spherulites occur above the contact but are less abundant than below. Core locally is poorly recovered and broken to rubble above the contact.

Spherulite-rich subzone (pul1) - A gradational contact identified as the interval above which lithophysal cavities are absent and spherulites common. In some locations this interval overlies zone pmn; in other locations it lies within zone pul.

\section{crystal-poor middle nonlithophysal zone (Tpcpmn)}

upper subzone (pmn3) - A sharp to gradational contact identified as the point or interval above which lithophysae are absent, the rock fractures along smooth, high-angle planes, and the rock has a brownish-red or red-purple matrix.

lithophysae-bearing subzone (pmn2) - A sharp to gradational contact identified as the point or interval above which lithophysae are present, the rock fractures in a semi-rough fashion, and the rock has a red-purple matrix. Vapor-phase alteration is more prevalent in this subzone than in super- and subjacent subzones. Core locally is poorly recovered and broken to rubble above this contact.

lower subzone (pmn1) - A sharp to gradational contact identified as the point or interval above which lithophysae are absent, the rock fractures along smooth, high-angle planes, and the rock has a reddish-brown, pale red, or grayishorange-pink matrix.

crystal-poor lower lithophysal zone (Tpcpll)

A gradational contact identified as the interval above which the rock fractures in a semi-rough fashion and above which lithophysae comprise more than 2 volume percent by visual estimate. Core locally is poorly recovered and broken to rubble above the contact. Below the contact, fractures are dominantly irregular, the amount of lithophysae decrease downward from less 
than 2 percent to zero, and the extent of vaporphase alteration diminishes downward.

crystal-poor lower nonlithophysal zone (Tpcpln)

hackly subzone (plnh) - A sharp to gradational contact identified as the point or interval above which the rock fractures in a predominantly irregular fashion, forming polygonal faces. Comparatively smooth, typically high-angle fractures dominate below the contact. Where gradational or layered, the contact is designated at the lowest occurrence of irregular fractures.

columnar subzone (plnc) -

spherulitic pumice interval (plnc3) - A gradational contact identified as the point or interval above which a devitrified matrix encloses pumice clasts that are predominantly spherulitically devitrified. Pumice clasts altered to clay occur in minor amounts above the contact.

argillic pumice interval (plnc2) - A sharp to gradational contact identified as the point or interval above which pumice clasts are commonly pinkish-orange and altered to clay, and enclosed in a devitrified matrix.

vitric pumice interval (plnc1) - A sharp contact identified as the point above which a devitrified matrix encloses deformed, vitric pumice clasts (typically black). The unit is locally absent.

crystal-poor vitric zone (Tpcpv)

vitrophyre subzone (pv3) - A sharp contact identified as the point above which the rock is a densely fused mass with a black to reddishbrown, glassy matrix that lacks a vitroclastic texture. The unit is locally absent.

moderately welded subzone (pv2) - A generally sharp contact identified as the point above which pumice clasts are deformed, matrix porosity decreases, matrix foliation increases, and the rock fractures across grain boundaries. Pumice clasts retain macroscopic porosity despite upwardly increasing deformation. Light brown glass shards are typical of this subzone. Locally, the matrix is partially devitrified.

non- to partially welded subzone (pv1) - A depositional contact identified as the point above which pumice clasts are not deformed, matrix foliation is weak to absent, the matrix has macroscopic porosity, and the rock breaks along grain boundaries. The subzone, which lies atop a moderate red paleosol, includes locally preserved pumice-fall (coarse, clast-supported pumice) and pyroclastic-surge (fine-grained laminar to cross-bedded ash) deposits. Light brown, dark grayish-brown, black, or colorless glass shards with bubble-wall textures typify this subzone.

\section{Pre-Tiva Canyon Tuff bedded tuff (Tpbt4)}

A sharp depositional contact above which is a clast-supported, pumiceous, lithic-rich fallout deposit (as in UZ\#16 and UZN-33), or the nonto partially weided subzone of the crystal-poor vitric zone of the Tiva Canyon Tuff (Tpcpv1) that contains light brown to clear glass shards and typically contains pink to brown clayaltered pumice clasts (as in UZN-53, UZN-54, and UZN-55). The top of the Yucca Mountain Tuff is marked by a distinctive pink paleosol.

\section{Yucca Mountain Tuff (Tpy)}

A sharp depositional contact above which is the nonwelded base of the light tan to light gray, vitric Yucca Mountain Tuff. The tuff contains distinctive clear glass shards, pink clay-altered pumice clasts, and less than 1 volume percent crystals. A coarse, clast-supported, pumicefall deposit of a few centimeters thickness occurs locally at the base of the unit.

\section{Pre-Yucca Mountain Tuff bedded tuff (Tpbt3)}

A sharp depositional contact above which is a nonwelded, pumice-fall deposit that is partly reworked. This deposit typically grades upward from clast-supported to matrixsupported. Overlying this deposit is a sequence of pyroclastic-flow, fallout, and reworked deposits that vary in thickness and preservation. 


\section{Pah Canyon Tuff (Tpp)}

A sharp depositional contact above which is the nonwelded, pumiceous, pyroclastic-flow deposit of the Pah Canyon Tuff. The basal Pah Canyon Tuff typically has a pinkish-gray or grayish-orange matrix that grades upward to grayish-orange-pink or pinkish-gray; pumice clasts are light gray in the basal part of the tuff but change upward to light gray and yellowishorange, the latter are distinctively crystal-rich.

\section{Pre-Pah Canyon Tuff bedded tuff (Tpbt2)}

A sharp depositional contact that is marked by a thin, lithic-rich fallout deposit that overlies a light red to pink ash about 2 centimeters thick. Above the contact is an altered, pumiceous tuff.

\section{Topopah Spring Tuff (Tpt)}

\section{crystal-rich vitric zone (Tptrv)}

non- to partially welded subzone (rv3) - A gradational contact identified as the interval above which pumice clasts are not deformed, matrix foliation is weak to absent, the matrix has macroscopic porosity, and the rock fractures along grain boundaries. This unit is intensely altered.

moderately welded subzone (rv2) - A sharp contact identified as the point above which pumice clasts retain macroscopic porosity despite strong deformation. The rock fractures across grain boundaries, but the matrix generally lacks macroscopic porosity.

vitrophyre subzone (rv1) - A sharp contact identified as the point above which the rock is a densely fused mass with a glassy matrix that lacks a vitroclastic texture (pumice clasts may be devitrified or altered by vapor-phase minerals).

\section{crystal-rich nonlithophysal zone (Tptrn)}

nonlithophysal subzone (m2) - A sharp to gradational contact identified as the point or interval above which the phenocryst content of the matrix exceeds 10 to 12 volume percent of the rock by visual estimate and above which lithophysal cavities are absent. Pumice clasts commonly comprise greater than 10 volume percent above the contact. The contact with subzone rl 2 is identified as the point above which lithophysal cavities are absent, and above which the percentage of recovered core is generally greater and vapor-phase alteration of the rock matrix typically is less intense.

crystal transition subzone (m1) - A gradational contact identified as the point above which the phenocryst content of the matrix increases upward from a minimum of 3 volume percent, with oxidized (bronze-colored) biotite and pyroxene pseudomorphs present. The phenocryst content is comparatively constant below the contact; the percentage of recovered core generally increases above this contact. This unit is present only where subzone rl2 is absent.

crystal-rich lithophysal zone (Tptrl)

lithophysal subzone (rl2) - A gradational contact identified as the interval above which phenocryst content exceeds 10 to 12 volume percent of the rock by visual estimate.

crystal-transition subzone (rl1) - A gradational contact identified as the interval above which phenocryst content increases upward from a minimum of 3 volume percent, with oxidized (bronze-colored) biotite and pyroxene pseudomorphs present. The phenocryst content is comparatively constant below the contact. Devitrified matrix grades from light brown above the contact to reddish-purple below the contact.

crystal-poor upper lithophysal zone (Tptpul)

cavernous lithophysae subzone (pul2) - A gradational contact above which small lithophysae (less than 5 centimeters) are sparse to absent, and the core is mostly rubble. Review of downhole video tape reveals abundant large lithophysae with diameters greater than 10 centimeters.

small lithophysae subzone (pul1) - A gradational contact identified as the interval above which the rock contains abundant small (less than 5 centimeters) lithophysal cavities, has a 
matrix that is variably vapor-phase altered, and fractures in an irregular manner. The devitrified matrix typically is red-purple, with abundant pinkish-gray spots of vapor-phase minerals.

crystal-poor middle nonlithophysal zone (Tptpmn)

upper subzone (pmn3) - A sharp to gradational contact above which lithophysae are absent and the rock fractures along smooth, highangle planes. The matrix above the contact typically has a light brown color.

lithophysae-bearing subzone (pmn2) - A sharp to gradational contact identified as the point or interval above which lithophysae are present and the rock fractures in a semi-rough fashion. Vapor-phase alteration of the light brown matrix is more prevalent in this subzone than in super- and subjacent subzones.

lower subzone (pmn1) - A sharp to gradational contact above which lithophysae are absent, the rock fractures along smooth, high-angle planes, and the extent of vapor-phase alteration decreases. The percentage of core recovery typically is greater above the contact than below.

crystal-poor lower lithophysal zone (Tptpll)

A gradational contact identified as the interval above which the rock fractures in a semi-rough fashion and above which lithophysae are present. Lithophysal content is generally less than 10 percent, with spots of vapor-phase minerals imparting a mottled texture to the rock above the contact. The amount of lithophysae decreases downward to less than 1 percent above the contact; lithophysae are absent below the contact. The matrix is a variable mix of light brown and pale red above the contact.

crystal-poor lower nonlithophysal zone (Tptpln)

A sharp contact above which the rock matrix is devitrified and the rock breaks along smooth, high-angle, curviplanar fractures. The matrix is pale red, grayish-orange, or pale yellowishbrown above the contact. crystal-poor vitric zone (Tptpv)

vitrophyre subzone (pv3) - A sharp contact identified as the point above which the rock is a densely fused mass with a grayish-black, glassy matrix that lacks a vitroclastic texture.

moderately welded subzone (pv2) - A generally sharp contact identified as the point above which pumice clasts are deformed, matrix porosity decreases, matrix foliation increases, and the rock breaks across grain boundaries. Pumice clasts retain macroscopic porosity despite upwardly increasing deformation. Black glass shards are typical of this subzone.

non- to partially welded subzone (pvl) - A depositional contact identified as the point above which pumice clasts are not deformed, matrix foliation is weak to absent, the matrix has macroscopic porosity, and the rock breaks along grain boundaries. The subzone lies atop a locally preserved pumice-fall deposit.

\section{Pre-Topopah Spring Tuff bedded tuff (Tpbt1)}

A sharp depositional contact above which is a medium- to fine-grained, typically light gray, pumice-fall deposit. Pyroclastic-flow deposits of the Calico Hills Formation occur below the contact.

\section{Calico Hills Formation (Tac)}

A sharp depositional contact above which is medium bedded ( 3 to 60 centimeters thick), fine- to coarse-grained, immature sandstone or reworked tuff. The base locally is an altered, lithic-rich, pumice-fall deposit. Below the contact is a light brown to pale brown, nonwelded, pyroclastic-flow deposit of the Prow Pass Member of the Crater Flat Tuff. 


\section{APPENDIX 2. TABLES OF LITHOLOGIC CONTACTS IN BOREHOLES AT}

YUCCA MOUNTAIN, NEVADA 
Table of Basal Lithologic Contacts in Borehole USW UZN-27

(Data Tracking Number: GS940208314211.004)

Unit*

$\underline{\text { UZN-27 }}$

Tiva Canyon Tuff (Tpc)

crystal-rich member (Tpcr)

nonlithophysal zone (m)

pumice-poor subzone (rn3)

\begin{tabular}{cc} 
mixed pumice subzone (rn2) & 7.2 \\
\hline $\begin{array}{c}\text { crystal transition subzone (rn1) } \\
\text { upper lithophysal zone (pul) }\end{array}$ & 52.7 \\
\hline $\begin{array}{c}\text { middle nonlithophysal zone (pmn) } \\
\text { lower lithophysal zone (pll) }\end{array}$ & 191.8 \\
\hline
\end{tabular}

Total Depth ==:====:======:======: 202.4

* Stratigraphic subdivisions follow the nomenclature defined by D.C. Buesch and others (USGS, written commun. 1994). Depths are in feet. 
Table of Basal Lithologic Contacts in Boreholes USW UZN-31, USW UZN-32 and USW UZN-37

(Data Tracking Number: GS940208314211.005)

$\underline{\text { Unit* }}$

$\underline{\text { UZN-31 UZN-32 UZN-37 }}$

Alluvium/Colluvium (QTac)

$==============$
Tiva Canyon Tuff (Tpc)

surface

surface

36.3

crystal-poor member (Tpcp)

lower nonlithophysal zone (pln)

hackly subzone (plnh)

columnar subzone (plnc)

crystal-poor vitric zone (pv)

moderately welded subzone (pv2)

non- to partially welded subzone (pv1)

$=========================$
Pre-Tiva Canyon bedded tuff (Tpbt4)

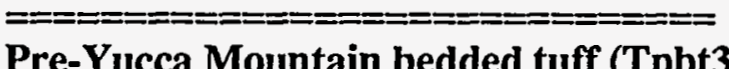

$==========================$

Pah Canyon Tuff (Tpp)

$==========================0$

Bedded tuffs (Tpbt2)

Topopah Spring Tuff (Tpt)

$88.7 \quad 96.0 \quad-3-109.4$

$102.7 \quad 107.5 \quad-121.0$

$106.7=0==113.1=127.7$

$111.5==119.0=======137.6 \pm 3.3$

$119.6=148.2$

$144.5==219.6$

$160.4=235.5$

crystal-rich member (Tptr)

vitric zone (rv)

non- to partially welded subzone (rv3)

moderately welded subzone (rv2)

vitrophyre subzone (rv1)

$174.4 \quad 247.5$

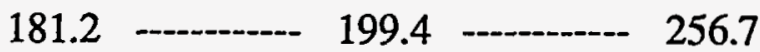

$185.5 \quad-202.4 \quad 258.0$

nonlithophysal zone (rn)

Total depth

$192.6=207.4=====271.3$

* Stratigraphic subdivisions follow the nomenclature defined by D.C. Buesch and others (USGS, written commun. 1994). Depths are in feet. 
Table of Basal Lithologic Contacts in Boreholes USW UZN-33 and USW UZN-34

(Data Tracking Number: GS940208314211.006)

Unit*

$\underline{\mathrm{UZN}-33} \quad \underline{\mathrm{UZN}-34}$

Alluvium/Colluvium (QTac)

Tiva Canyon Tuff (Tpc)

$13.1^{\dagger}====50.1$

crystal-poor member (Tpcp)

vitric zone (pv)

moderately welded subzone (pv2)

non- to partially welded subzone (pv1)

Bedded Tuff (Tpbt4)

Yucca Mountain Tuff (Tpy)

Total depth

22.6

$44.2=====* * *$

47.3

22.6

7.3 $=====* * *$

$75.0====84.1$

* Stratigraphic subdivisions follow the nomenclature defined by D.C. Buesch and others (USGS, written commun. 1994). Depths are in feet.

$\uparrow$ No core above $13.1 \mathrm{ft}$.

*** Unit does not occur in this hole; contact is between super- and subjacent units. 
Table of Basal Lithologic Contacts in Borehole USW UZN-35

(Data Tracking Number: GS940208314211.007)

Unit* $^{*}$

$\underline{\mathrm{UZN}-35}$

Alluvium/Colluvium (QTac)

Tiva Canyon Tuff (Tpc)

crystal-poor member (Tpcp)

middle nonlithophysal zone (pmn)

\begin{tabular}{|c|}
\hline lower lithophysal zone (pll) \\
\hline Breccia Zone \\
\hline $\begin{array}{l}\text { Tiva Canyon Tuff (Tpc) } \\
\text { crystal-poor member (Tpcp) } \\
\text { lower nonlithophysal zone (pln) } \\
\text { hackly subzone (plnh) }\end{array}$ \\
\hline
\end{tabular}

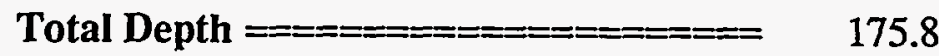

* Stratigraphic subdivisions follow the nomenclature defined by D.C. Buesch and others (USGS, written commun. 1994). Depths are in feet. 


\section{Table of Basal Lithologic Contacts in Boreholes USW UZN-53, USW UZN-54, and USW UZN-55 \\ (Data Tracking Number: GS940208314211.003)}

$\underline{\text { Unit }}$

$\underline{\text { UZN-53 }}$

$\underline{\mathrm{UZN}-54}$

$\underline{\mathrm{UZN}-55}$

Alluvium/Colluvium (QTac)

\begin{tabular}{|c|}
\hline $\begin{array}{l}\text { Tiva Canyon Tuff (Tpc) } \\
\text { crystal-poor member (Tpcp) } \\
\text { middle nonlithophysal zone (pmn) }\end{array}$ \\
\hline lower lithophysal zone (pll) \\
\hline $\begin{array}{l}\text { lower nonlithophysal zone (pln) } \\
\text { hackly subzone (plnh) }\end{array}$ \\
\hline columnar subzone (plnc) \\
\hline $\begin{array}{l}\text { vitric zone (pv) } \\
\quad \text { moderately welded subzone (pv2 }\end{array}$ \\
\hline non- to partially welded subzon \\
\hline Yucca Mountain Tuff (Tpy) \\
\hline Pre-Yucca Mountain bedded tuff (Tpbt3) \\
\hline
\end{tabular}

$2.1======19.0=====$ surface

****

***

42.4

44.2

55.9

92.5

99.2

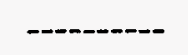

91.0

126.0

150.6

145.5

177.0

159.2

158.8

190.0

$173.4=====$

$167.7====203.9 \pm 1.3$

$180.3=====$

$175.5====213.9 \pm 1.1$

$195.6=====$

$191.4====221.3 \pm 3.8$

213.8

210.3

226.7

Topopah Spring Tuff (Tpt)

crystal-rich member (Tptr)

vitric zone (rv)

non- to partially welded subzone (rv3)

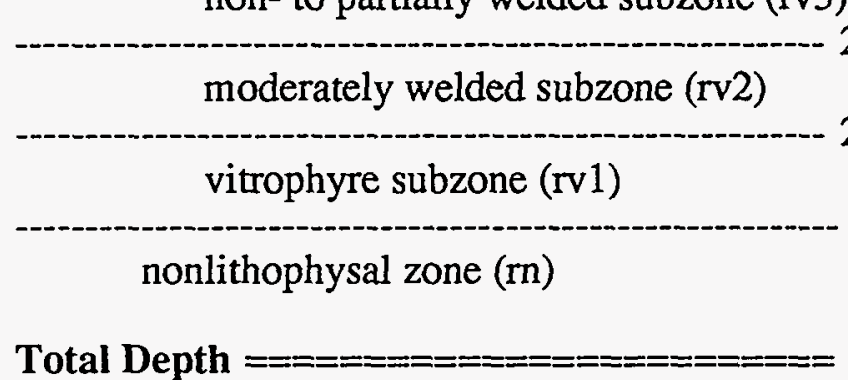
$222.4 \pm 1.0$ $231.9 \pm 0.5$

$$
\text { *** }
$$

*** 246.6

$234.5=====$

244.7

255.3

Note: *** indicates the absence of the crystal-poor middle nonlithophysal zone of the Tiva Canyon Tuff and the crystal-rich vitrophyre subzone of the Topopah Spring Tuff in boreholes UZN-53 and UZN-54; contacts occur between the super- and subjacent units. Yucca Mountain Tuff includes an overlying thin, pumiceous fallout and paleosol (Tpbt4). Stratigraphic subdivisions follow the nomenclature defined by D.C. Buesch and others (USGS, written commun. 1994). 
Table of Basal Lithologic Contacts in Boreholes USW UZN-57, USW UZN-58, USW UZN-59, and USW UZN-61

(Data Tracking Number: GS940208314211.008)

Unit*

$\underline{\text { UZN-57 }} \underline{\text { UZN-58 }} \quad \underline{\mathrm{UZN}-59} \quad \underline{\mathrm{UZN}-61}$

Alluvium/Colluvium (QTac)

Topopah Spring Tuff (Tpt)

$1.2^{\dagger}==22.1^{\dagger}===13.1^{\dagger}==9.8^{\dagger}$

crystal-rich member (Tptr)

vitric zone (rv)

moderately welded subzone (rv2)

vitrophyre subzone (rv1)

nonlithophysal zone (rn)

lithophysal zone (rl)

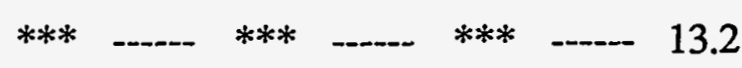

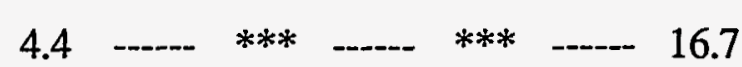

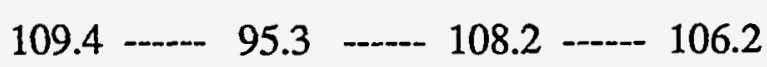

Total Depth

$118.9===118.9===118.8==118.9$

* Stratigraphic subdivisions follow the nomenclature defined by D.C. Buesch and others (USGS, written commun. 1994). Depths are in feet.

$\dagger$ No core above $1.2 \mathrm{ft}$. (UZN-57); 8.9 ft. (UZN-58); $13.1 \mathrm{ft}$. (UZN-59); $9.8 \mathrm{ft}$. (UZN-61).

*** Unit is not present, contact occurs between overlying and underlying units. 
Table of Basal Lithologic Contacts in Borehole USW UZN-62

(Data Tracking Number: GS940208314211.002 )

$\underline{\text { Unit }}$

$\underline{\mathrm{UZN}-62}$

Alluvium/Colluvium (QTac)

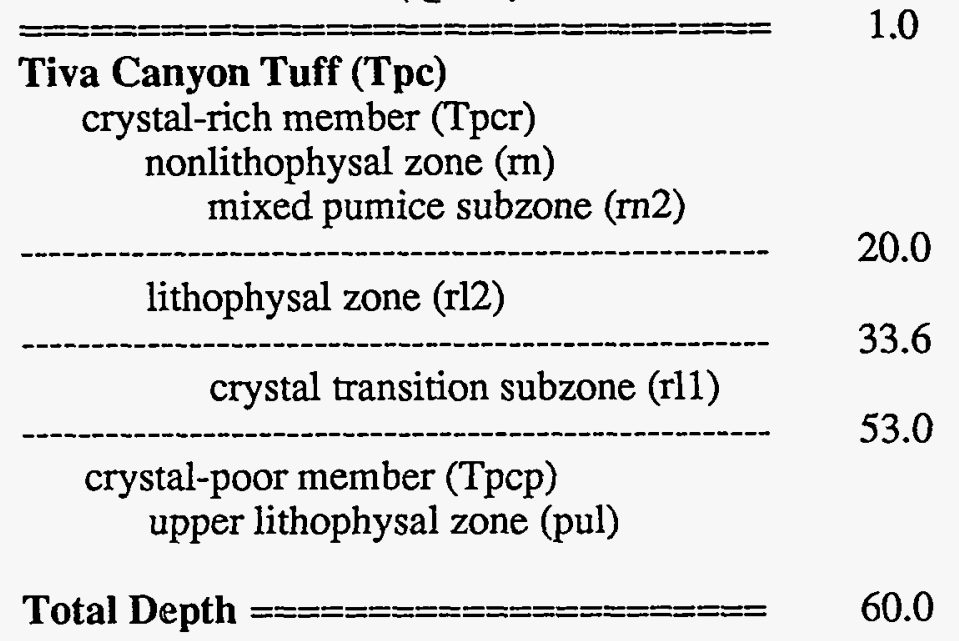

Stratigraphic subdivisions follow the nomenclature defined by D.C. Buesch and others (USGS, written commun. 1994) 


\section{Table of basal contacts from core in boreholes USW UZ-14 and USW NRG-7/7A: An interim report}

(Data Tracking Number: GS940108314211.001)

The following table summarizes the depth to basal contacts of stratigraphic units in boreholes USW UZ-14 and USW NRG-7/7A. Buesch determined contacts in UZ-14, and Geslin and Moyer determined contacts in NRG-7/7A. Moyer reviewed contacts in UZ-14, and Buesch reviewed contacts for NRG-7/7A. Contacts are determined from examination of core stored at the Sample Management Facility. Minor revisions in these contacts may occur after examination of core removed at the drill site and review of video logs of core. Stratigraphic subdivisions follow the nomenclature defined by D.C. Buesch and others (USGS, written commun. 1994).

USW UZ-14 is a vertical hole with a collar location at $771,321 \mathrm{~N}, 560,144 \mathrm{E}$, and elevation of 4425 feet. Drilling of this borehole is in progress, so the location is the surveyed position of the hole prior to drilling. This is not the as-built location, and has been rounded to the nearest foot. UZ-14 is continuously cored from the surface to $1,434.6$ feet, the deepest core available for examination as of January 18,1994. Lithostratigraphic units in the core include Yucca Mountain, Pah Canyon, and Topopah Spring Tuffs, nonwelded tuffs that are interstratified with each of these formations, and Calico Hills Formation.

USW NRG-7/7A is a vertical hole with a collar location at 768,880 N, $562,984 \mathrm{E}$, and elevation of 4,207 feet. Drilling of this borehole is in progress, so the location is the surveyed position of the hole prior to drilling. This is not the as-built location, and has been rounded to the nearest foot. NRG-7/7A is continuously cored from the surface to 995.4 feet , the deepest core available for examination as of January 18, 1994. Lithostratigraphic units in the core include Tiva Canyon, Yucca Mountain, Pah Canyon, and Topopah Spring Tuffs, and nonwelded tuffs that are interstratified with each of these formations. 
Tiva Canyon Tuff (Tpc)

crystal-poor member (Tpcp)

lower nonlithophysal zone (pln)

hackly subzone (plnh) (contact indistinct)

columnar subzone (plnc)

vitric zone (pv)

moderately welded subzone (pv2)

non- to partially welded subzone (pv1)

pre-Tiva Canyon Tuff bedded tuff (Tpbt4)

Yucca Mountain Tuff (Tpy)

pre-Yucca Mountain Tuff bedded tuff (Tpbt3)

Pah Canyon Tuff (Tpp)

pre-Pah Canyon Tuff bedded tuff (Tpbt2)

Topopah Spring Tuff (Tpt)

crystal-rich member (Tptr)

vitric zone (rv)

non- to partially welded subzone (rv3)

moderately welded subzone (rv2)

vitrophyre subzone (rv1)

nonlithophysal zone (m)

lithophysal zone (rl)

lithophysal subzone (rl2)

crystal transition subzone (rl1)

crystal-poor member (Tptp)

lithophysal zone (pul)

cavernous lithophysae subzone (pul2)

small lithophysae subzone (pul1)

middle nonlithophysal zone (pmn)

upper subzone (pmn3)

lithophysae-bearing subzone (pmn2)

lower subzone ( $\mathrm{pmn} 1$ )

lower lithophysal zone (pll)

lower nonlithophysal zone (pln)

vitric zone (pv)

vitrophyre subzone (pv3)

moderately welded subzone (pv2)

non- to partially welded subzone (pv1) none

41.0 ?

$170.0 \pm 1$

$79.2 \pm 0.8$

$102.3 \pm 0.8$

none

$106.4 \pm 1.5$

78.2

$1058.0 \pm 2.1$

102.1

$175.8 \pm 0.9$

240.4

$258.8 \pm 0.9$

258.6

263.1

280.9

$292.7 \pm 0.6$

282.5

286.0

430.0

$296.1 \pm 1.2$

300.4

478.2

452.8

489.5

468.0

518.4

489.5

715.0

$* * *$

768.5

765.5

811.6

802.0

855.8

828.0

877.6

1138.0

1279.1

1344.0

1383.0

1404.2

21434.6

2995.4

Calico Hills Formation

Notes: Depths are in feet.

1 Contacts where samples have been removed prior to examination of core are indicated by $\mathrm{a} \pm$ interval.

2 Lowest core examined as of January 18, 1994. Base of unit not penetrated. 


\section{APPENDIX 3. GRAPHICAL LITHOLOGIC LOGS FOR BOREHOLES AT YUCCA MOUNTAIN, NEVADA}


Borehole : UE-25 NRG \#1

Data Tracking Number: GS931208314211.046

\section{Zones of welding (W)}

Moderately to Densely

(o-lithophysae)

Partially to Moderately

Non- to Partially

Nonwelded

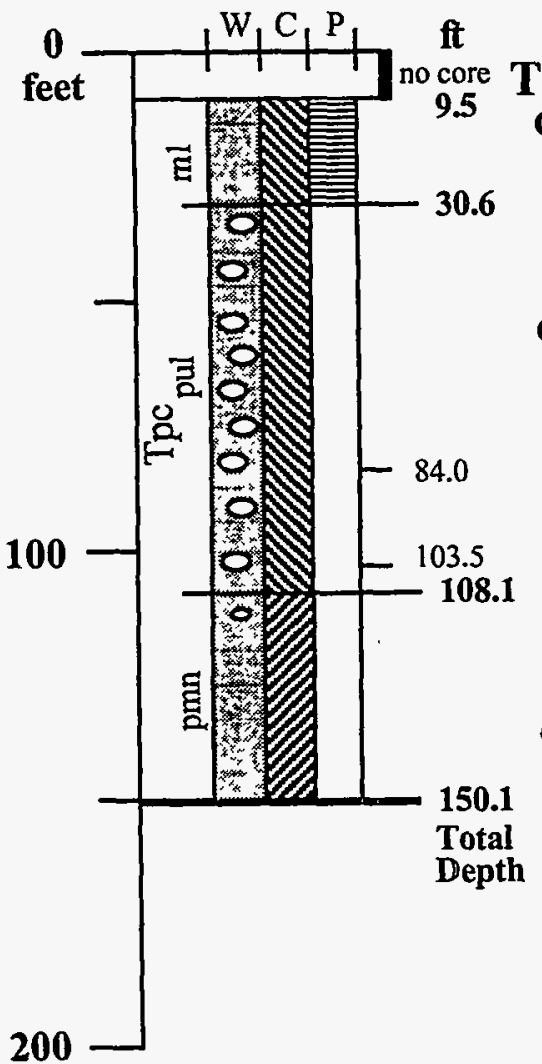

\section{Zones of crystallization (C)}

Devitrified / Devit. + vapor-phase mins.

Vitric / Vitric + vapor-phase mins.

Altered (a) / to clay (c) / to zeolite (z)

\section{Phenocryst content (P)}

Fi. greater than 10 percent

$5-10$ percent

less than 5 percent

crystal transition subzone ( $r n 1)$ : 7-10 percent very light gray (N8), vapor-phase altered to corroded pumice clasts in a patchy, light gray (N7) to grayish orange-pink (5YR7/2; percent of this color increases downward) matrix. Phenocrysts (7-10 percent decreasing downward to about 5 percent) of feld, oxybio, altered cpx.

Crystal-poor upper lithophysal zone (pul; 30.6-108.1):

Matrix is a patchy mix of grayish orange-pink (5YR7/2; 70 percent) and light gray (N7; 30 percent), lithophysae (about 2 percent from 30.6 to $47.0 \mathrm{ft} ; 5-10$ percent from 47.0 to $87.0 \mathrm{ft}$; $1-2$ percent from 87.0 to $108.1 \mathrm{ft}$ ) are lenticular, $1-5 \mathrm{~cm}$ in length, with very light gray (N8) rims. Crystals are mostly feld with rare oxybio, altered cpx; pumice clasts (3-5 percent) are elongate, commonly very light gray (N8), rarely dark yellowish brown (10YR3/2) and crystalrich. Spherulites, commonly cored by felsic phenocrysts, are sparse from 53.0 to $84.0 \mathrm{ft}$ and 103.5 to $108.1 \mathrm{ft}$.

84.0-103.5 - spherulite-rich subzone (pull): Few lithophysae (less than 2 percent); spherulites $(2-5 \mathrm{~mm}$ ) comprise up to 30 percent of matrix.

Crystal-poor middle nonlithophysal zone (pmn; 108.1-TD):

Pale red (5R6/2) matrix with streaks of light gray (N7); scattered (less than 1 percent) lithophysae to $130.0 \mathrm{ft}$, rare (much less than 1 percent) below. Light gray (N7) volcanic lithic clasts (less than 1 percent) mostly less than $3 \mathrm{~mm}$ but up to $8 \times 16 \mathrm{~mm} ; 1-3$ percent very light gray (N8) pumice clasts, locally spherulitically devitrified. Phenocrysts are mostly feld with rare oxybio. High-angle fracture at $127.2 \mathrm{ft}$ has calcite coating opal. 
Borehole : UE-25 NRG \#2 (30 slant toward S80E)

Data Tracking Number: GS931008314211.039

\section{Zones of welding (W) Zones of crystallization (C)}

Moderately to Densely

(o-lithophysae)

Partially to Moderately

Non- to Partially

Nonwelded

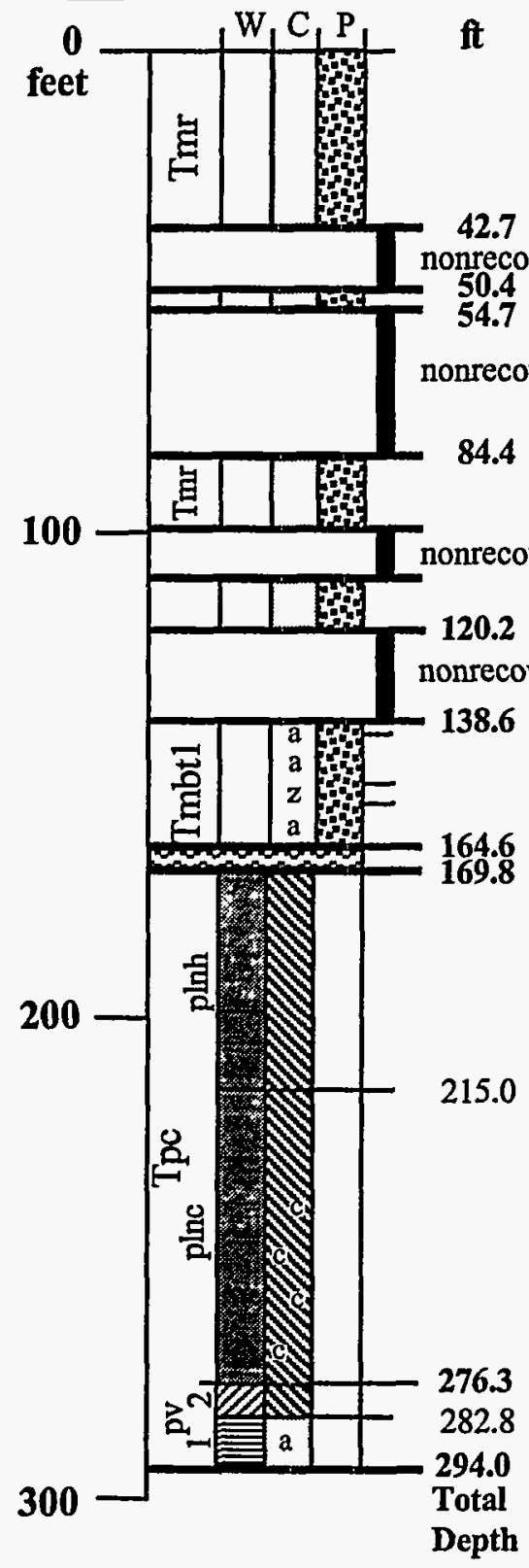

recovered

50.4

4.4

120.2
Devitrified / Devit. + vapor-phase mins.

Vitric / Vitric + vapor-phase mins.

Altered (a) / to clay (c) / to zeolite (z)

\section{Phenocryst content (P)}

greater than 10 percent

$5-10$ percent

less than 5 percent nrecovered

Bedded tuff (Tmbt1) -

Pyroclastic flow (138.6-141.7), pyroclastic flow (141.7-152.0), lapilli fallout (152.0156.0), pyroclastic flow (156.0-164.6)

Grayish orange (10YR7/3) matrix; pumices (5-10 percent in flows, 30-40 percent

in fall) are white (N9) or yellow green (5Y8/2) where zeolitized; volcanic lithics (10-15 percent) are dark grayish red (7.5R3/2); crystals include feld, vitric qtz, fresh or (oxy)bio, \pm hbld.

Bow Ridge Fault - rubble and nonrecovered interval from 164.6 to $169.8 \mathrm{ft}$

Tiva Canyon Tuff (Tpc) -

Crystal-poor lower nonlithophysal zone (pln; 169.8-276.3):

169.8-215.0 hackly subzone (plnh): Matrix is reddish brown (10R4/4) to moderate brown (5YR3/4); volcanic lithics (less than 5 percent) (most less than $2 \mathrm{~mm}$ ) are grayish brown (5YR3/1); less than 2 percent lithophysae (up to $6 \mathrm{~cm}$ ) with vapor-phase minerals and light-gray (N7) rims; abundance of pumice increases near base to 10-15 percent; abundant irregular fractures and rare smooth high-angle fractures, some light-gray (N7) rims and white (N9) mineral coatings.

215.0-276.3 columnar subzone (plnc): Matrix is orange pink (5YR7/3) grading downward to light reddish gray (2.5YR7/1) to yellowish brown (10YR6/4); pumices (10-15 percent at top to less than 5 percent near base) $(10-20 \mathrm{~mm})$ define moderate foliation, are dark grayish red (10R3/1), spherulitic (some axiolitic), or replaced by grayish pink (5R8/2) clay; volcanic lithics (less than 5 percent) (less than $10 \mathrm{~mm}$ ) are grayish brown (5YR3/1); smooth, high-angle fractures. Phenocrysts are feld, rare hbld and $\operatorname{cpx}(?)$.

Crystal-poor vitric zone (pv; 276.3-294.0):

276.3-282.8 moderately welded subzone (pv2): Matrix is orange pink (7.5YR7/3) and partially to completely devitrified with shard texture more pronounced near base; pumices (1-3 percent) (less than $15 \mathrm{~mm}$ ) are pinkish gray (2.5YR7/1), devitrified and contain vapor-phase minerals; volcanic lithics (1-2 percent) (less than $10 \mathrm{~mm}$ ) are grayish brown (5YR3/1).

282.8-294.0 non-to partially welded subzone (pv1): Matrix is orange pink (7.5YR7/4), partially devitrified and contains reddish-yellow (7.5YR6/8) glass; pumices (3-5 percent) $(10-20 \mathrm{~cm})$ are reddish yellow (7.5YR6/8) or altered grayish orange pink (5YR7/2); volcanic lithics (5 percent) $(10-20 \mathrm{~mm})$ are grayish brown (5YR3/1). 
Borehole : UE-25 NRG \#2A

Data Tracking Number: GS931008314211.038

\section{Zones of welding $(W)$}

Moderately to Densely (o-lithophysae)

Partially to Moderately

Non- to Partially

Nonwelded

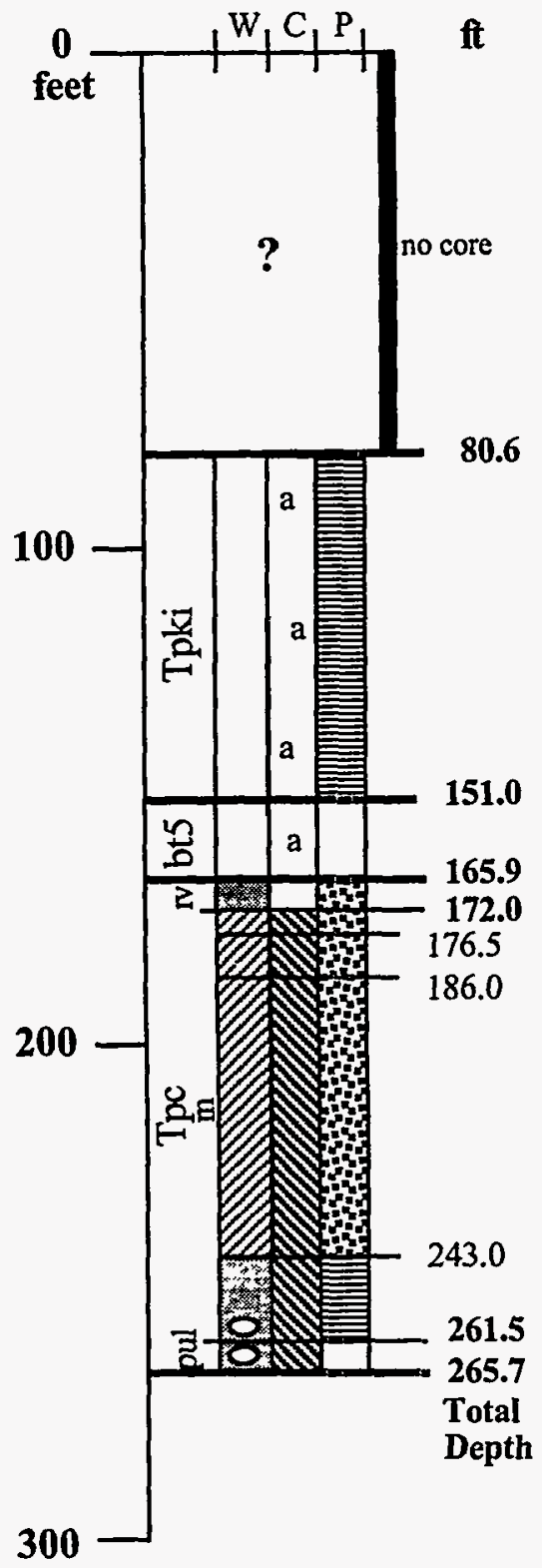

\section{Zones of crystallization (C)}

Devitrified/Devit. + vapor-phase mins.

Vitric / Vitric + vapor-phase mins.

ca

Altered (a) / to clay (c) / to zeolite (z)

\section{Phenocryst content (P)}

Exid greater than 10 percent

$5-10$ percent

less than 5 percent

\section{Alluvium/Colluvium (QTac) ?}

cuttings not examined above $80.6 \mathrm{ft}$.

\section{Tuff unit "x" (Tpki) -}

matrix is white to very light gray (N9-N8) and slightly altered; pumice (20-30 percent) is very light gray (N8) to light brown (5YR6/4); volcanic lithic clasts (3-5 percent) are grayish brown (5YR3/2), reddish brown (2.5YR3/4) or grayish black (N2); basal (1 ft thick) wellsorted lapilli fallout deposit

Bedded tuff minimum of four reworked (?) well-sorted, pumiceous lapilli fallout anc (Tpbt5) - poorly-sorted pyroclastic flow deposits; several brown to very palc

\section{Tiva Canyon Tuff (Tpc) -}

Crystal-rich vitric zone (rv; 165.9-172.0): elongate light gray and yellow-brown pumice (N7-N8, 7.5YR4/6), 10-15 percent phenocrysts.

165.9-168.0 Non- to partially welded subzone ( $r 33)$ : incipiently devitrified, pinkish brown (2.5YR6/2).

168.0-170.2 Moderately welded subzone ( $r 22)$ : incipiently devitrified, grayish red (2.5YR3/2).

170.2-172.0 Vitrophyre subzone ( $r v 1)$ : moderate brown to very dark gray (5YR4/3 to N3) glass, well-foliated, locally spherulitic.

Crystal-rich nonlithophysal zone ( $r$; 172.0-261.5):

172.0-176.5 Subvitrophyre transition ( $r n 4)$ : dark reddish gray to light grayish brown (10R4/1 to $2.5 Y R 5 / 2$ ), pumice (5-10 percent) are argillically altered.

176.5-186.0 Pumice-poor subzone (m3): light pinkish brown (2.5YR5/3), less than 5 percent pumice.

186.0-243.0 Mixed pumice subzone ( $r$ 2): brownish pink to reddish gray (10R6/2 to 10R6/1), pumices (less than 30 percent) are brownish gray and light gray (5YR4/1 and $\mathrm{N} 8)$ and replaced with vapor-phase minerals.

243.0-261.5 Crystal transition subzone ( $\mathrm{ml}$ ): decrease downward in pumice from 15-20 percent to 5-7 percent and in phenocrysts from 10-12 percent to less than 5 percent, scattered (much less than 5 percent) lithophysae below $245 \mathrm{ft}$.

Crystal-poor upper lithophysal zone (?) (pul; 261.5-265.7): reddish gray (10R6/1) rubble. 
Borehole : UE-25 NRG \#2B

Data Tracking Number: GS931108314211.041

Zones of welding (W)

Moderately to Densely (o-lithophysae)

Partially to Moderately

Non- to Partially

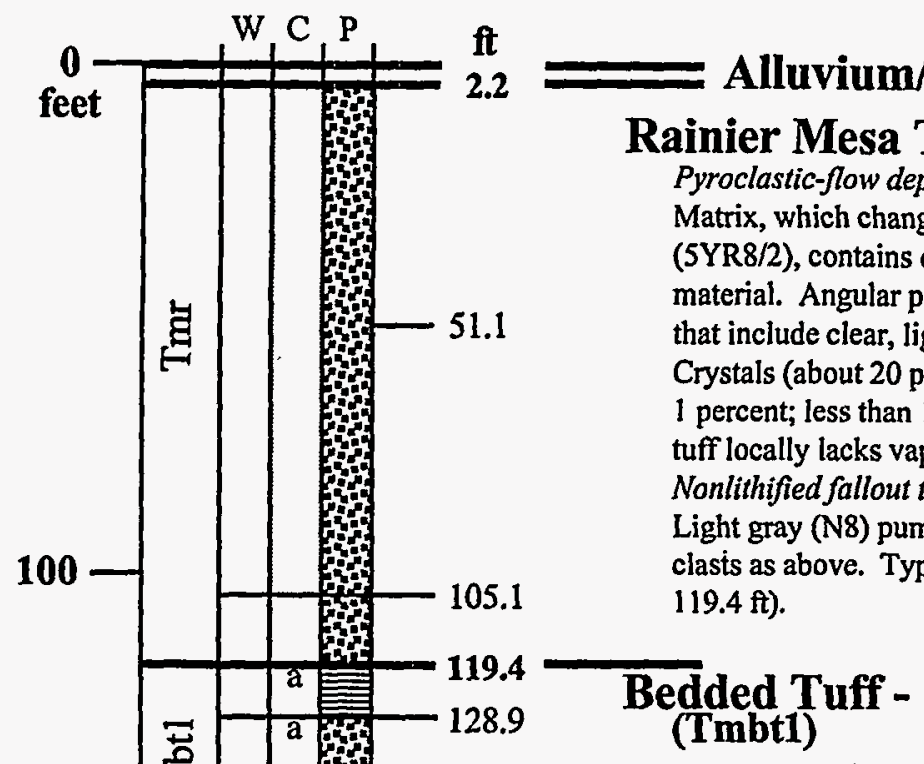

\section{$\square$ Nonwelded}

Zones of crystallization (C)

Devitrified / Devit. + vapor-phase mins.

Vitric / Vitric + vapor-phase mins.

Altered (a) / to clay (c) / to zeolite (z)
Phenocryst content (P)

greater than 10 percent

$5-10$ percent

less than 5 percent

Ligh gays pin (7.5YR8/2), qtz, (oxy)bio. 128.9-142.5. Pyroclastic-now deposit

142.5 Light grayish pink (7.5YR8/2) with glass shards and 15-20 percent white (N9) pumice less than $5 \mathrm{~mm}$. Crystals of feld, qtz, bio. 142.5-157.3: Pyroclastic flow. Pinkish gray (7.5YR7/3) with glass shards and 10 percent light gray (N8) pumice, most $1-3 \mathrm{~mm}$. Crystals of feld, qtz, bio, hbld. Lithic- and crystal-rich zone at 151.3-151.4 fi, dips at about $16^{\circ}$.

Tuff Unit " $x$ " (Tpki) -

Altered matrix, very light gray (10YR8/1) to light reddish gray (2.5YR8/1) to very pale yellow (2.5Y9/2). Vitric pumice clasts (15-20 percent) are yellowish gray (5Y7/2); zeolitized are grayish yellow (5Y8/4) or pale orange (10YR8/3). Volcanic lithics (5-7 percent) are dark gray (N3), dark reddish gray (10R3/1), or pale reddish brown (10R5/4). May be fallout from 229.7-230.7' $\mathrm{ft}$ Basal $1.5 \mathrm{ft}$ is a separate unit that is altered, $5-7$ percent white pumice in grayish pink matrix (7.5YR7/3).

232.3

Bow Ridge Fault Zone - Slightly to extremely altered, broken to intact core with nonrecovered intervals. Identifiable lithologic units include pyroclastic-flow deposit, Tpcrn, nonlithophysal Tpcp.

260.0

Bedded Tuff (Tpbt3) - 260.0-274.8: Nonwelded, fine-grained, pumiceous pyroclasticflow deposit. 274.8-277.2: Crudely stratified, poorly-sorted, lithic and pumice-rich fallout; dips at about $3^{\circ}$. 277.2-285.3: Nonwelded, fine-grained, pumiceous pyroclastic-flow deposit

285.3 (?) or reworked. Lithic-rich zone at 278.3-278.4 ft dips at about $5^{\circ}$.

Pah Canyon Tuff (Tpp)- Grayish orange pink (10R8/2) matrix; pumice (15-30 percent): light gray only (N8-9) above $305.2 \mathrm{ft}$, light gray and large (up to $40 \times 80 \mathrm{~mm}$ ), pale yellowish orange (10YR8/6) with distinctive crystal clots from $305.2 \mathrm{ft}$ to $322.0 \mathrm{ft}$; light gray only from 322.0-324.0 ft in pinkish gray (5R8/1) matrix. Crystals of feld, bio, cpx.

324.0

329.5

Total

Depth
Bedded Tuff (Tpbt2) - 324.0-329.4: Altered pumiceous tuff. Very pale orange (10YR8/2) pyroclastic-flow deposit with small (less than $10 \mathrm{~mm}$ ), pumice; crystals of feld and bio; may be 2 units. 329.4-329.5: Pink clay-rich pumice lapilli fallout (?). 
Borehole : UE-25 NRG \#3

Data Tracking Number: GS931008314211.037

\section{Zones of welding $(W)$}

Moderately to Densely (o-lithophysae)

Q Partially to Moderately

Non- to Partially

Nonwelded

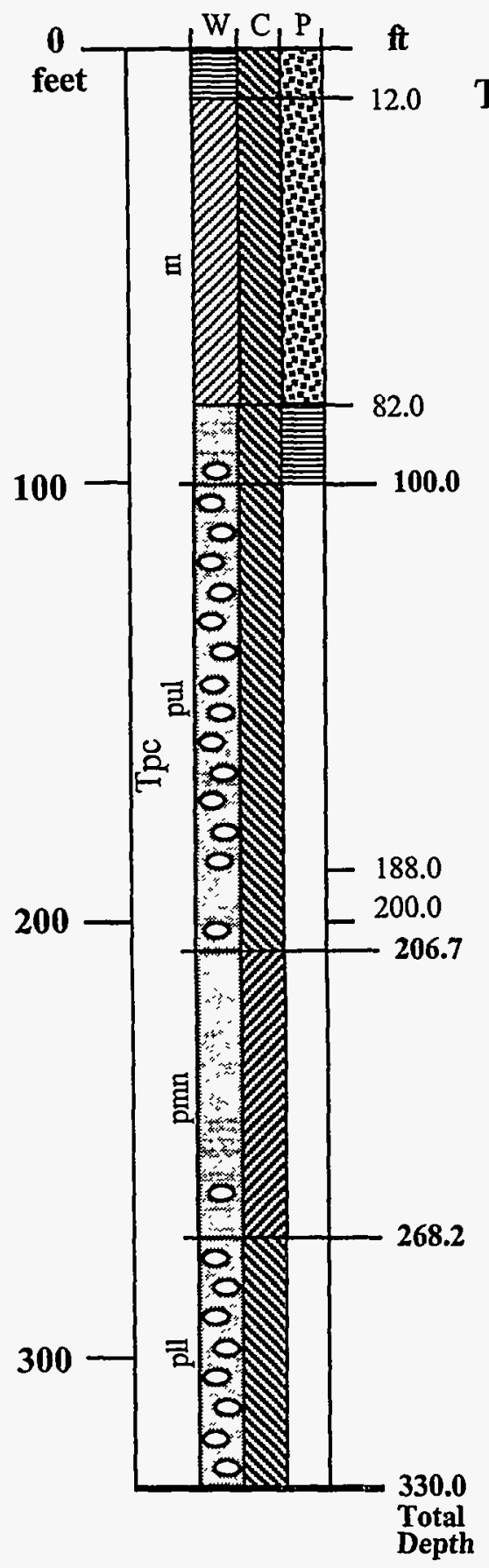

\section{Zones of crystallization (C)}

Devitrified / Devit. + vapor-phase mins.

Vitric / Vitric + vapor-phase mins.

Altered (a) / to clay (c) / to zeolite (z)

\section{Phenocryst content (P)}

59 greater than 10 percent

5 - 10 percent

less than 5 percent

\section{Tiva Canyon Tuff (Tpc) -}

Crystal-rich nonlithophysal zone (rn; 0-100.0):

0-12.0 Pumice-poor subzone (rn3): Pale red (10R6/2), less than 5 percent pumice.

12.0-82.0 Mixed pumice subzone (rn2): Pale grayish red to pale pink (5R5/2 to 5RP7/2), pumice clasts are brownish gray and light gray (5YR4/1 and N8) and replaced with vaporphase minerals.

82.0-100.0 Crystal transition subzone ( $r n l)$ : Decrease downward in pumice clasts from 1520 percent to 5-7 percent, and in phenocrysts from greater than 10 percent to less than 5 percent; rare lithophysae near base.

Crystal-poor upper lithophysal zone (pul; 100.0-206.7):

Grayish pink to grayish red ( $5 R 8 / 2$ to $10 R 4 / 2$ ), lithophysae (about 20 percent) are $1-3$ $\mathrm{cm}$ and have thin (few $\mathrm{mm}$ ), very light gray (N8) rims.

188.0-200.0 Spherulite-rich subzone (pull): Few lithophysae, spherulites are 1-3mm and commonly cored by felsic phenocrysts.

Crystal-poor middle nonlithophysal zone (pmn; 206.7-268.2):

Pale red to grayish red-purple (5R6/2 to 5RP5/2), few scattered lithophysae (much less than 5 percent). Smooth high-angle fractures.

\section{Crystal-poor lower lithophysal zone (pll; 268.2-330.0):}

Pale red (5R6/2) to grayish orange-pink (5YR7/2) below $295 \mathrm{ft}$, lithophysae are $3-4 \mathrm{~cm}$ with light gray (N7) rims. 


\section{Zones of welding (W) Zones of crystallization (C)}

Moderately to Densely (o-lithophysae)

Partially to Moderately

Non- to Partially

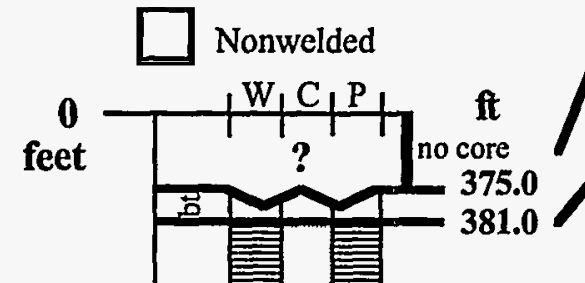

Bedded tuffs (Tpbt3) -
Devitrified / Devit. + vapor-phase mins.

Vitric / Vitric + vapor-phase mins.

Altered (a) / to clay (c) / to zeolite (z)

\section{Phenocryst content (P)}

greater than 10 percent

$5-10$ percent

\section{$\square$ less than 5 percent}

400

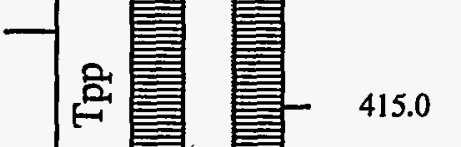

Well-sorted, vitric, pumice lapilli fallout overlain by coarse, pumiceous pyroclastic flow and possible reworked fallout. Pumice is light gray (N8), crystals of feld, qtz, bio.

\section{Pah Canyon Tuff (Tpp) -}

Pumice (15-25 percent), up to $8 \times \sqrt{3} \mathrm{~cm}$, light gray (N8) and yellowish orange (7.5YR7/6) with crystal clots. Matrix varies downward from grayish orange-pink (5YR7/3) to grayish orange (7.5YR7/4). Crystal content increases from 5-10 percent to 10-15 percent downward, mostly feld and bio, lesser qtz and cpx. Volcanic lithic clasts, generally less than $10 \mathrm{~mm}$, comprise 1-5 percent. 381.0-415.0: both pumice types; 415.0-447.7' yellow-orange pumice only; 447.7-458.0: light gray pumice only (zeolitized (10Y8/2) below 452.0 ).

Bedded tuffs (Tpbt2) -

458.0-462.5 Pumiceous luff. Matrix is light brown (7.5YR6/3), crystals: feld, bio, $\pm q \mathrm{tz}$; altered pumice (10-30 percent; $1-15 \mathrm{~mm}$ ) is $10 \mathrm{Y} 8 / 2$ or 5 YR5/6; volcanic lithics (10 percent, less than 5 mm). 462.5-468.1 Nonwelded fallout. Top is pinkish (5R7/2) clay-rich layer $0.7 \mathrm{ft}$ thick. Matrix grades downward from pinkish gray (5R8/2) to light grayish orange (10YR7/3). Altered pumice (about 50 percent) up to $2.5 \mathrm{~cm}$ is white. Crystals: feld, (oxy)bio, hbld, rare cpx. Lithics, moderate brown (5YR4/3) and dark gray (N3), are less than $7 \mathrm{~mm}$. Lithic clast at 465 is $30 \mathrm{~mm}$, finely crystalline, bio-rich, cognate(?). Two silicified ash layers in lower $0.5 \mathrm{ft}$.

\section{Topopah Spring Tuff (Tpt) -}

Crystal-rich vitric zone (rv; $468.1-488.9$ ):

468.1-485.0 Moderately welded subzone ( $r v 2)$ : Top is pink (5R7/2), lithic-rich fall (0.1 $\mathrm{ft}$ thick). Degree of welding increases downward; matrix changes from yellowish brown (7.5YR6/6) and pink $(2.5 Y R 7 / 2)$ to light grayish red $(10 \mathrm{R} 6 / 1)$ as argillic alteration is replaced by vapor-phase mineralization. Pumice, $1-3 \mathrm{~cm}$, is grayish orange pink (5YR7/2) to light greenish gray $(5 \mathrm{GY} 7 / 1)$. Crystals: feld, oxybio, thbld, tcpx. 485.0-488.9 Vitrophyre subzone (rv1): Dark reddish brown glass (2.5YR3/3) with black glassy fiamme (less than 2-3 cm; 5-10 percent). Crystals: feld, (oxy)bio, hbld, cpx.

Crystal-rich nonlithophysal zone (rn; 488.9-660.5):

Matrix grades from pinkish gray (10R6/1) to light brown (5YR6/6) as percent devitrified material increases downward. Intense vapor-phase from 540.5-546.5. Reddish gray (2.5YR5/1) pumices only above 525 and together with light gray (N7) pumices below 525. Pumice (5-8 percent, locally 10-15 percent) is mostly less than $2 \mathrm{~cm}$ but with clasts greater than $3.5 \mathrm{~cm}$ below 547; flattening defines foliation; vapor-phase minerals: $\mathrm{SiO} 2$, specularite, nutile and pseudobrookite(?). Crystals: feld, (oxy)bio, hbld, cpx (altered below 638'). Lithic clasts (much less than 1 percent) light gray (N9), finely crystalline. Uncoated fractures are moderately irregular; coated fractures are smooth. Crystal-rich lithophysal zone (rl; 660.5-710 \pm 2$)$ :

660.5-683 \pm 2 : Large $(3 \times 6 \mathrm{~cm})$ lithophysae comprise 5 percent. Matrix is well-foliated (moderate brown 5YR5/4). Light gray (N9), moderate gray (N6), and rare reddish gray (10R6/1) pumice (total 10 percent), vapor-phase altered to corroded. Crystals: feldspar, (oxy)bio, hbld, cpx (altered). Lithics, much less than 1 percent, white (N9), finely crystalline. Nonrecovered and rubbly intervals are common. $683 \pm 2-710 \pm 2$ Crystal transition subzone (rl1): Lithophysae (1x2.5 cm, up to $2.5 \times 10$ $\mathrm{cm}$ ) comprise greater than 10 percent. Pale red purple (5RP7/2) matrix and pale red (10R6/1) and light gray (N9) pumice are vapor-altered. Crystal content decreases from 10-15 percent at 675 to 5 7 percent at 695 to 3-5 percent at 705, mafic minerals decrease sharply downward. Below 690 , cpx is rare, biotite is oxidized.

Crystal-poor upper lithophysal zone (pul; 710 $\pm 2-T D)$ :

Unrecovered and rubbly intervals common. Reddish purple (5RP5/2) matrix; moderate brown (5YR5/4) pumice ( 5 percent) is less than $1-2 \mathrm{~cm}$, vapor-altered; crystals (less than 3 percent) are mostly feldspar. Lithophysae (greater than 5 percent?) are greater than $3 \times 10 \mathrm{~mm}$ commonly $10 \times 40$ $\mathrm{mm}$, have light-gray (N7) rims of less than $2 \mathrm{~mm}$. Fracture is very irregular. 
Borehole : UE-25 NRG \#5

Data Tracking Number: GS931108314211.043

\begin{tabular}{|c|c|c|}
\hline Zones of welding (W) & Zones of crystallization (C) & Phenocryst content $(P)$ \\
\hline $\begin{array}{l}\text { Moderately to Densely } \\
\text { (o-lithophysae) }\end{array}$ & Devitrified / Devit. + vapor-phase mins. & greater than 10 percent \\
\hline Partially to Moderately & Vitric / Vitric + vapor-phase mins. & $5-10$ percent \\
\hline Non- to Partially & Altered (a) / to clay (c) / to zeolite (z) & less than 5 percent \\
\hline
\end{tabular}

Nonwelded

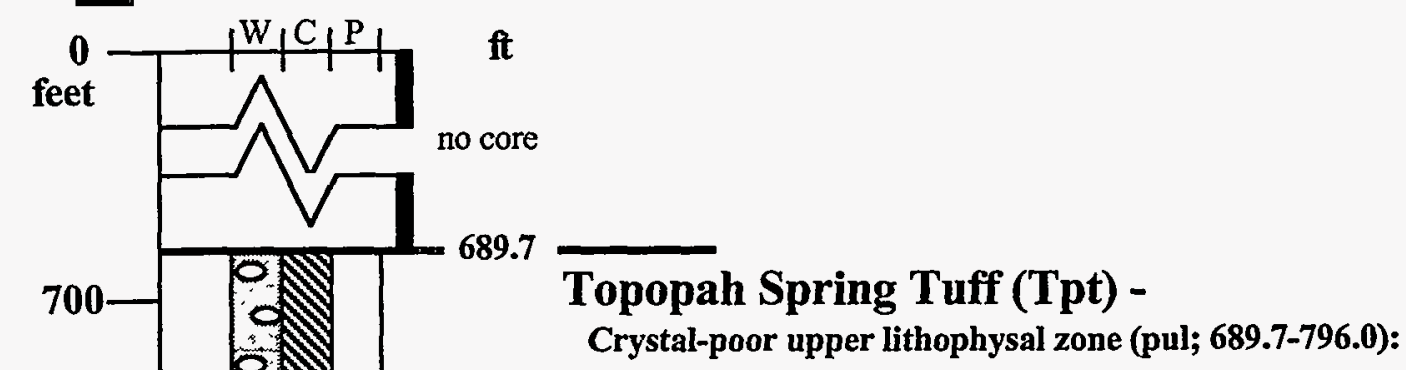

Core is mostly rubble; grayish red purple and pale brown (5RP4/2 and 5YR5/2) matrix; about 5 percent visible lithophysae (up to $10 \times 35 \mathrm{~mm}$ ), with very light gray (N8) rims (up to $20 \mathrm{~mm}$ ); most lithophysae are represented by unrecovered intervals and rubble, very light gray (N8) spots (up to $40 \mathrm{~mm}$ ); crystals (1-2 percent) include feld and bio; low-angle irregular fractures. Lower contact is gradational from 790 to 806 ; contact at first high-angle fractures.

Crystal-poor middle nonlithophysal zone (pmn; 796.0-901.5):

796.0-845.0 Upper subzone (pmn3)/869.0-901.5 Lower subzone (pmn1) - Grayish orange pink (5YR7/2) matrix; smooth high-angle fractures with very light gray (N8) alteration rims, filled with abundant white (N9) and rare, dendritic black (N1) (MnO?) minerals, slickensides at 817.0; rare (less than 1 percent) lithophysae and very light gray (N8) spots (most less than $10 \mathrm{~mm}$ ); crystals ( $1-2$ percent) include feld and bio.

845.0-869.0 Lithophysal-bearing subzone (pmn2) - Grayish orange pink to red purple (5YR7/2 to 5RP5/2) matrix; lithophysae (about 5 percent) (up to $20 \times 45 \mathrm{~mm}$ ) with light-gray (N7) rims, abundant (10-25 percent) light-gray spots (less than $10-40 \mathrm{~mm}$ ).

901.5

Crystal-poor lower lithophysal zone (pll; 901.5-995.9):

Core is mostly rubble; matrix is mottled pale brown, yellowish brown and pale red (5YR5/2, 5YR6/6 and 5R6/2); less than 5 percent visible lithophysae (up to $35 \times 50 \mathrm{~mm}$ ), with very light gray (N8) rims; most lithophysae are represented by unrecovered intervals and rubble; abundant (20-25 percent) very light gray (N8) spots; white (N9) aphyric volcanic lithics (up to 5 percent); crystals ( $1-2$ percent) include feld and bio; irregular fractures.

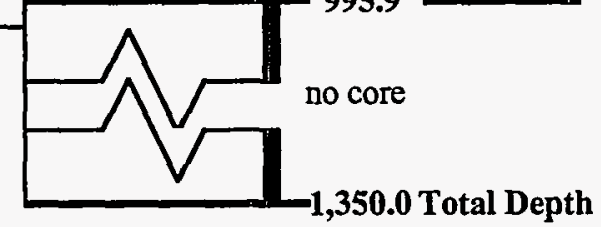


Zones of welding (W)

Moderately to Densely

(o-lithophysae)

Partially to Moderately

Non- to Partially
Zones of crystallization (C)

武

Devitrified / Devit. + vapor-phase mins.

Vitric / Vitric + vapor-phase mins.

Altered (a) / to clay (c) / to zeolite (z)

\section{Phenocryst content (P)}

10 greater than 10 percent

\section{5 - 10 percent}

less than 5 percent

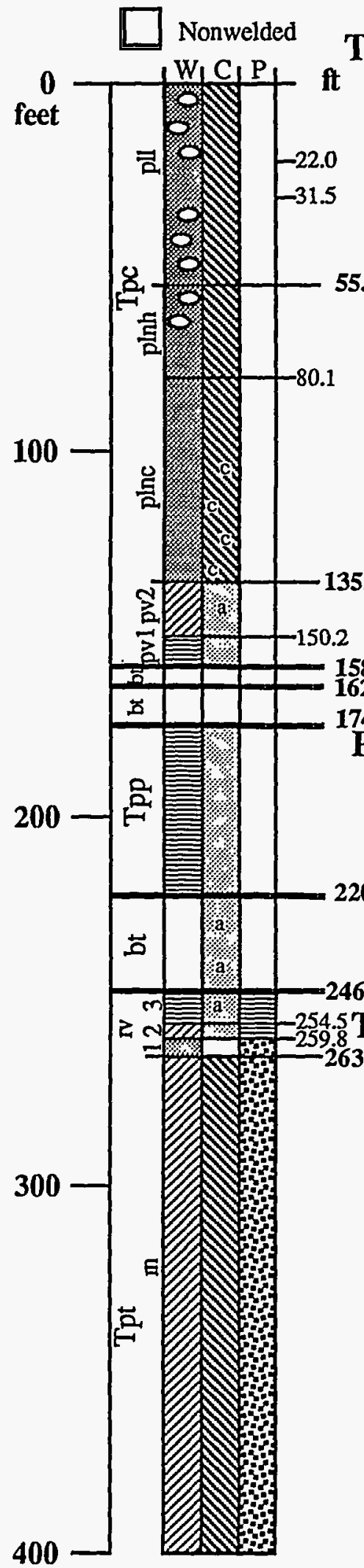

\section{Tiva Canyon Tuff (Tpc) -}

Crystal-poor lower lithophysal zone (pll; 0.0-55.0):

Lithophysae content ranges from 2 percent at $0-10$ to 25 percent at $15-20$ to 3-5 percent at 32-55 ft, most are 20-30 mm (up to $80 \mathrm{~mm}$ ). 2-3 percent phenocrysts, feld, cpx and bio (?). Matrix is light brownish gray (5YR6/1) and red purple (5RP5/2) at 0-20 and brownish gray (5YR5/1) below 20, 3-10 percent light-gray (N7) spots. 22.0-31.5 nonlithophysal interval, mineral-coated, smooth, high-angle fractures.

Crystal-poor lower nonlithophysal zone (pIn; 55.0-135.3):

55.0-80.1- Hackly subzone ( $p$ lnh) - upper $11 \mathrm{ft}$ contain 2-3 percent lithophysae; upper contact based on the 55.0 first appearance of irregular fractures. Pumice textures (gray, N4-N5, most $<10 \mathrm{~mm}$ ) visible below 57 and are 2-3 percent of rock near base of unit, some are spherulitic. Phenocrysts (3 percent) include feld, oxybio (?) and cpx. Matrix is brownish gray (5YR5/1) and red purple (5RP5/2) with 3-5 percent light-gray (N7) spots above 66. Abundant rough, subhorizontal fractures.

80.1-1353-Columnar subzone (plnc) - Pumice increases downward from 2 to 5 percent, most less than 10 $\mathrm{mm}$ (up to $40 \mathrm{~mm}$ ), filled with vapor-phase minerals except where filled with pink (5R7/4) clay (rare clay from 91.5 to 106, abundant from 106 to 125.2). Phenocrysts (3 percent) include feld, cpx and bio (?). Matrix grades downward from pale purple (5R6/2) to light brownish gray (5YR6/1) to grayish pink (5R8/2). Abundant mineral-coated, smooth, high-angle fractures.

Crystal-poor vitric zone (pv; 135.3-158.8): $\quad$ Pumice (2 percent), altered, pinkish gray (5R8/2), up to 135.3-150.2 Moderately welded subzone (pv2) -25 mm. Matrix is yellowish brown (10YR6/4) with 135.3 150.2-158.6 Non- to partially welded subzone ( $p v 1)$ yellowish brown (7.5YR5/8) to black (N1) glass shards. Phenocrysts (2 percent) include feld and bio (?).

Bedded tuffs - 158.6-162.8 - Pre-Tiva Canyon bedded tuff(Tpbt4)/162.8-174.9 Pre-Yucca Mountain bedded tuff (Tpbt3) - Additional bedding breaks at 158.7, 159.6, 164.4.165.0. Four pumice and lithic-rich fallout deposits, two with paleosols; several normally graded horizons.

Pumice (15-25 percent), less than $20 \mathrm{~mm}$ (up to greater than $60 \mathrm{~mm}$ ), pinkish gray (5YR8/1) and grayish orange (10YR7/4, with crystal clots above about 181). Glassy to vapor-phase-altered matrix grades downward from pinkish orange (2.5YR7/6) to grayish orange (10YR7/4) to pinkish gray (5YR8/1). Phenocrysts (2-3 percent) are feld and (oxy)bio with rare qtz. Volcanic lithic clasts (less than 1 percent) generally less than $5 \mathrm{~mm}$.

220.8 Bedded tuffs (Tpbt2) -220.8-225.5 - Altered, pumiceous fallout deposit with paleosol; 225 5-238.7 - Altered, pumiceous fallout deposit with 8-10 cm pink (5R7/4) clay layer at top; 238.7-246.7 Altered, pumiceous, matrix-rich tuff. Other unit breaks present but less distinctive. Base is marked by a 1-cmthick, light red (5R6/6), lithic-rich fallout.

\subsection{Crystal-rich vitric zone (rv; 246.7-263.2):} 246.7-254.5 \pm 1.3 Non-to partially welded subzone ( $r v 3)$ - Pumice (10-40 percent) is mostly less than $10 \mathrm{~mm}$ (up to $40 \mathrm{~mm}$ ), vitric to altered, white (N9) and moderate pink (10R7/4). Phenocrysts include feld, oxybio and cpx. Matrix is yellowish brown (10YR5/6).

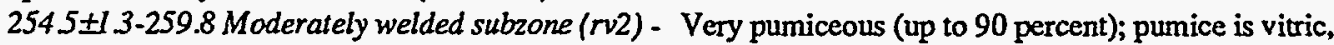
mostly less than $10 \mathrm{~mm}$ (up to $30 \mathrm{~mm}$ ), light brown (5YR5/6) and medium light gray (N6). Phenocrysts include feld, oxybio and hbld (?). Volcanic lithics (3-5 percent) are pale red (5R6/2).

259.8-263.2 Vitrophyre subzone ( $r v 1)$ - Pumice (2-5 percent) may be represented by black (N1) glass spots in matrix. Phenocrysts (15 percent) include feld, bio, cpx, and hbld (?). Matrix is grayish red (5R4/2) glass.

Crystal-rich nonlithophysal zone (rn; 263.2-429.0):

Pumice (5-10 percent) contains vapor-phase minerals, mostly less than $5 \mathrm{~mm}$ (up to $15 \mathrm{~mm}$ ) above 316 and mostly less than $20 \mathrm{~mm}$ (up to $80 \mathrm{~mm}$, the width of the core) below, pinkish gray (5YR8/1) and grayish red (5R3/2). Phenocrysts include feld, oxybio, cpx, and rare hbld. Matrix grades downward from dusky brown (5YR2/2) and moderate brown (5YR3/4) to grayish red (10R4/2) to red purple (5RP5/2) to pale red (5R6/2) to light brown (5YR5/6) and light brownish gray (5YR6/1). Degree of devitrification and vapor-phase mineralization increases downward; zone of intense vapor-phase mineralization at 309.3-315.9. 
Borehole : USW NRG-6

Data Trackin Number: GS931008314211.045

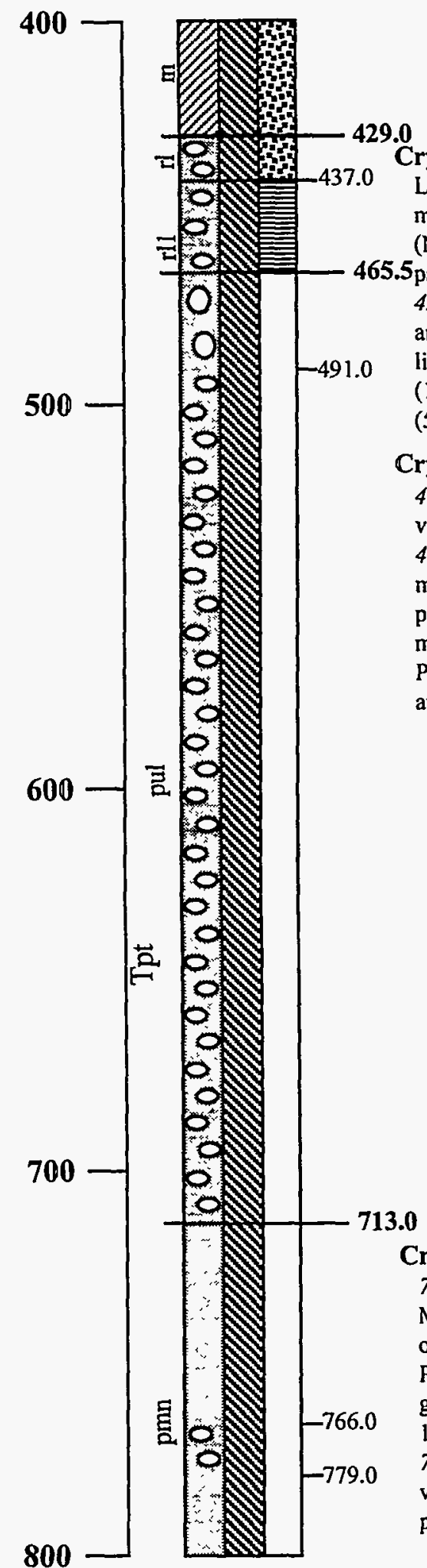

Crystal-rich lithophysal zone (rl; 429.0-465.5):

Lithophysae (10 percent) up to $65 \times 30 \mathrm{~mm}$. Pumice (5-10 percent) contains vapor-phase minerals, corroded, most less than $20 \mathrm{~mm}$ (up to $80 \mathrm{~mm}$, the width of the core), pale yellowish brown (10YR6/2) and light gray (N7). Phenocrysts (10 percent) include san, plag, oxybio, and altered cpx. Matrix is light brown (5YR5/6) and .5paie yellowish brown (10YR6/2).

437.0 $\pm 1.0-465.5 \pm 1.0$ Crystal transition subzone (rll) - Phenocrysts decrease downward from 10 to 3 percent, and include san, plag, (oxy)bio, and altered cpx. Lithophysae (10 percent) are up to $25 \times 32 \mathrm{~mm}$, and have very light gray (N8) rims. Pumice (15 percent), most less than $10 \mathrm{~mm}$ (up to $60 \mathrm{~mm}$ ), is pale yellowish brown (10YR6/2) and light gray (N7). Matrix grades downward from light brownish gray (5YR6/1) and light brown (5YR6/4) to red purple (5RP5/2).

Crystal-poor upper lithophysal zone (pul; 465.5 $\pm 1.0-713.0$ ):

465.5 $\pm 1.0-491.0$ Cavernous lithophysae subzone (pul2) - core is mostly red purple (5RP5/2) rubble with no visible lithophysae. Down-hole videotape reveals cavernous lithophysae (greater than $10 \mathrm{~cm}$ ).

491.0-713.0 Small lithophysae subzone (pull) - Lithophysae (5-20 percent), most less than $25 \mathrm{~mm}$ (up to 65 $\mathrm{mm}$ ), with very light gray (N8) spots. Lithophysae and spots make $20-40$ percent of rock. Pumice (5-10 percent at top of unit) decrease downward and no pumice textures are visible below about 550 . Pumice is mostly less than $30 \mathrm{~mm}$ (up to $80 \mathrm{~mm}$, the width of the core), pale brown (5YR5/3) and very light gray (N8). Phenocrysts (1-2 percent) include feld and rare oxybio. Matrix is a variable mixture of red purple (5RP5/2) and reddish orange (10R6/4). Rare (less than 1 percent) light gray (N7) volcanic lithics.

13.0

Crystal-poor middle nonlithophysal zone (pmn; 713.0-810.0):

713.0-766.0 Upper subzone (pmn3)/lower subzone (pmnl) - Phenocrysts (I percent) include feld and bio. Matrix is a variable mixture of red purple (5RP5/2) or pale red (5R4/2) and light brown (5YR5/6), with wisps of very light gray (N8). Abundant smooth high-angle fractures, some with white (N9) mineral coatings. Pumice (less than 1 percent above 766 and $1-5$ percent below) is mostly less than $20 \mathrm{~mm}$, spherulitic, and grayish brown (5YR3/2) and very light gray (N8). Volcanic lithics (1-2 percent) are light gray (N7), less than $10 \mathrm{~mm}$ and locally have very light-gray (N8) rims.

$766 \pm 2-779 \pm 1$ lithophysae-bearing subzone (pmn2) - - Lithophysae (less than 1 percent) up to $18 \times 80 \mathrm{~mm}$ with vapor-phase minerals and very light gray (N8) rims and spots. Lithophysae and spots represent about 5-7 percent of rock. 
Borehole : USW NRG-6

Data Tracking Number: GS931008314211.045

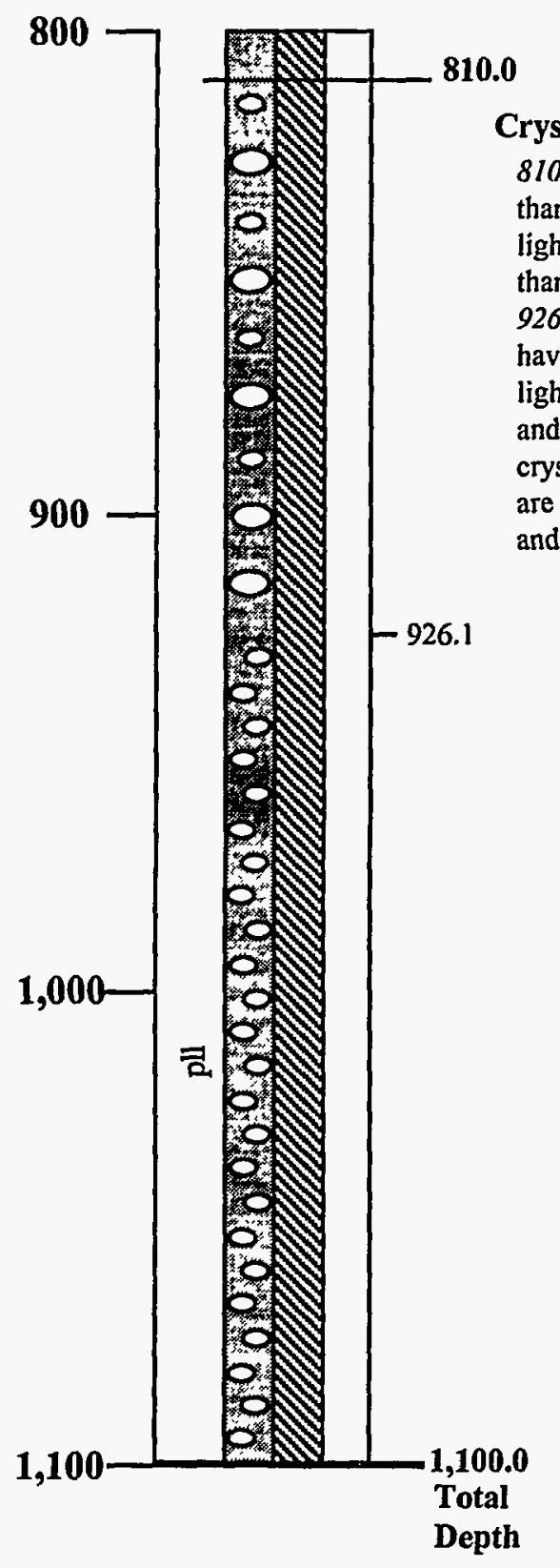


Borehole : UE-25 RF \#3

Data Tracking Number: GS931008314211.036

\section{Zones of welding $(W)$}

Moderately to Densely (o-lithophysae)

Partially to Moderately

Non- to Partially

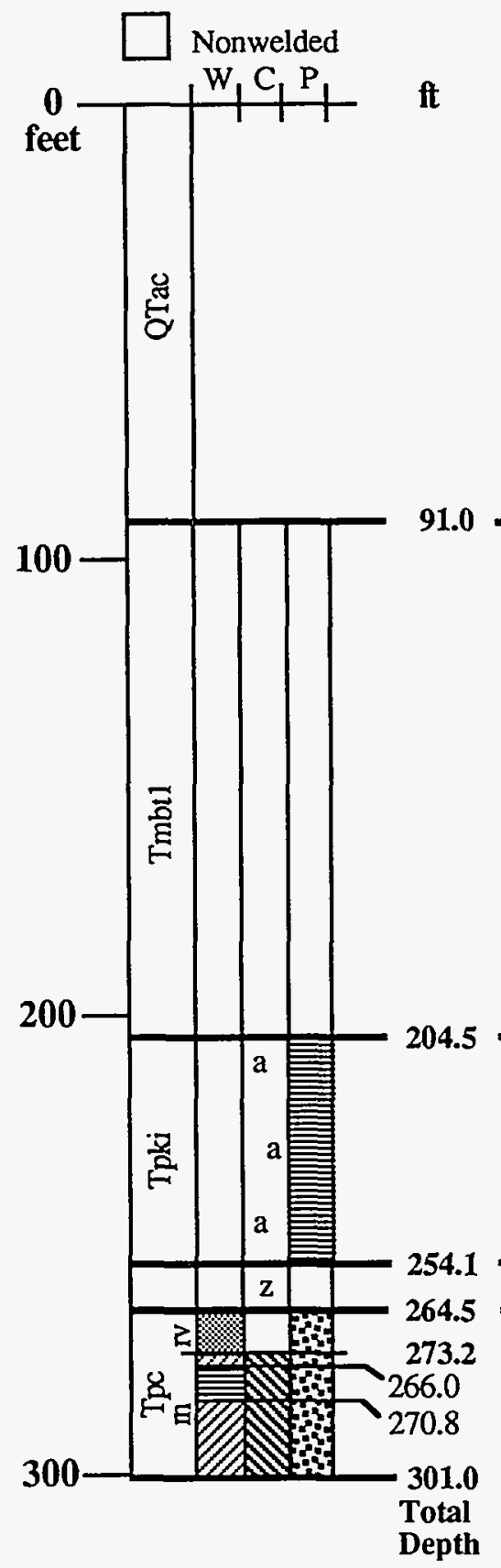

\section{Zones of crystallization (C)}

Devitrified / Devit. + vapor-phase mins.

Vitric / Vitric + vapor-phase mins.

Altered (a) / to clay (c) / to zeolite (z)
Phenocryst content (P)

Fif greater than 10 percent

5 - 10 percent

less than 5 percent

\section{Alluvium/Colluvium (QTac) -}

Polylithologic boulder conglomerate with pale orange-pink (7.5YR8/2), pebbly, fine-grained sandy matrix.

\section{Bedded tuffs (Tmbt1) -}

Volcaniclastic sandstone and reworked pyroclastic-flow deposits; matrix is pale orange (7.5YR8/2), muddy, fine-grained, pebbly, and poorly sorted; pumices are white and pale greenish yellow (N9 and 10Y8/2); volcanic lithics are pale red and brownish gray (5R6/2 and 5YR4/1); distinctive cross-bedding, cross-laminations (at 121.5 to $173.4 \mathrm{ft}$ ), and inverse grading (at 173.4 to $204.5 \mathrm{ft}$ ).

\section{Tuff unit "x" (Tpki) -}

Matrix is pinkish gray (5YR8/2) above $205.0 \mathrm{ft}$ and light gray (N8) below, slightly altered; pumices (up to 25 percent), very light gray (N8) are vitric or altered; volcanic and (rare) granitic lithic clasts (up to 15 percent) grayish red (5R4/2) and medium light gray (N6); $3-4 \mathrm{~cm}$ interbeds of fine-grained material may define flow-unit boundaries, several clay and silt-filled fractures; basal well-sorted lapilli fallout deposit.

\footnotetext{
reworked (?) pyroclastic-flow deposits, matrix is pinkish gray (5YR8/1); pumices (up to 30 percent) are white (N9) and pale greenish yellow (10Y8/2)

Bedded tuff - and altered (opal or zeolitized (?)); volcanic lithics (about 5 percent) are light (Tpbt5) brown (5YR5/6) and grayish red (5R4/2); cross-bedding below $260.6 \mathrm{ft}$.
}

\section{Tiva Canyon Tuff (Tpc) -}

Crystal-rich vitric zone (rv; 264.5-273.2): elongate, light gray and yellow-brown pumice (N7 to N8, 7.5YR4/6), 10-15 percent phenocrysts.

264.5-266.0 Non - to partially welded subzone ( $p v 3)$ : incipiently devitrified, pinkish brown (2.5YR8/2).

266.0-270.8 Moderately welded subzone (pv2): incipiently devitrified, brownish red (10R5/2). 270.8-273.2 Vitrophyre subzone ( $p v 1$ ): moderate brown to very dark gray (5YR5/6 to N3) glass, well-foliated.

Crystal-rich nonlithophysal zone (rn; 273.2-301.0):

273.2-276.4 Subvitrophyre transition ( $r n 4)$ : dark reddish gray to light grayish brown (10R4/1 to $2.5 \mathrm{YR} 5 / 2$ ), $5-10$ percent pumice.

276.4-284.0 Pumice-poor subzone $(r n 3)$ : dark reddish gray (10R4/2), less than 5 percent pumice.

284.0-301.0 Mixed pumice subzone ( $r n 2)$ : reddish gray (10R6/1), pumices ( $\leq 30$ percent) are brownish gray and light gray (5YR4/1 and N8) and replaced with vapor-phase minerals. 
Borehole : UE-25 RF \#8

Data Tracking Number: GS931008314211.035

\section{Zones of welding $(W)$}

Moderately to Densely

(0-lithophysae)

Partially to Moderately

Non- to Partially

Nonwelded

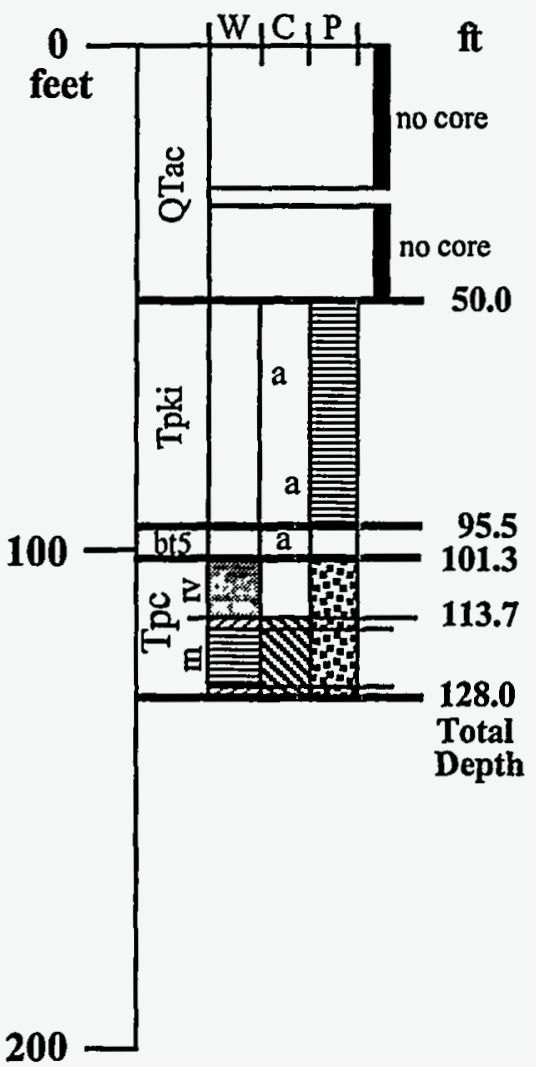

Zones of crystallization (C)

Devitrified / Devit. + vapor-phase mins.

Vitric / Vitric + vapor-phase mins.

Altered (a) / to clay (c) / to zeolite (z)

\section{Phenocryst content (P)}

greater than 10 percent

$5-10$ percent

less than 5 percent

\section{Alluvium/Colluvium (QTac) -}

Polylithologic pebble to cobble conglomerate with pinkish gray (7.5YR8/2), fine-grained sandy matrix.

\section{Tuff unit "x" (Tpki) -}

Matrix is white (N9) to pinkish gray (5YR8/2); vitric pumice clasts (20-25 percent) are grayish pink (10R8/2); volcanic lithic clasts (about 5 percent) are grayish red (5R4/2), grayish black (N3) and light gray (N8); basal, well-sorted lapilli fallout deposit.

Bedded tuff (Tpbt5) -

Reworked pyroclastic-flow deposits; matrix is very pale orange (10YR8/2) to grayish orange (10YR7/4); pumice clasts (up to 30 percent) are white (N9) to very light gray (N8) and altered; volcanic lithic clasts (5-8 percent); basal lapilli fallout deposit.

\section{Tiva Canyon Tuff (Tpc) -}

Crystal-rich vitric zone (rv; 101.3-113.7):

Variably elongated light gray and yellow-brown pumice (N7 to N8, 10YR6/8), 10-15 percent phenocrysts.

101.3-106.6 Non- to partially welded subzone (pv3): incipiently devitrified, grayish orange (10YR7/4).

106.7-108.9 Moderately welded subzone ( $p v 2)$ : devitrified, moderate brown (5YR3/4).

108.9-113.7 Vitrophyre subzone (pv1): moderate brown to very dark gray (5YR3/4 to N3) glass, well-foliated, spherulitic.

Crystal-rich nonlithophysal zone (rn; 113.7-128.0):

113.7-115.5 Subvitrophyre transition subzone ( $m 4)$ : dark reddish gray to light grayish brown (10R4/1 to $2.5 \mathrm{YR} 5 / 2)$, pumice (5-10 percent) is argillically altered.

115.5-127.2 Pumice-poor subzone.(m3): light pinkish brown (2.5YR5/3), less than 5 percent pumice.

127.2-128.0 Mixed pumice subzone ( $r n 2)$ : brownish pink to reddish gray (10R6/2 to 10R6/1), pumices (up to 30 percent) are brownish gray and light gray (5YR4/1 and N8) and replaced with vapor-phase minerals. 
Drill hole : UE-25 UZ \#16

Data Tracking Number: GS931208314211.047
Zones of welding (W)
Zones of crystallization (C)

\section{Phenocryst content (P)}
Moderately to Densely
Partially to Moderately
Devitrified / Devit. + vapor-phase mins.
greater than 10 percent
Partially to Moderately
Non- to Partially
D. Vitric / Vitric + vapor-phase mins.
㯺 $5-10$ percent
A. Altered (a) / to clay (c) / to zeolite (z)
less than 5 percent

Nonwelded

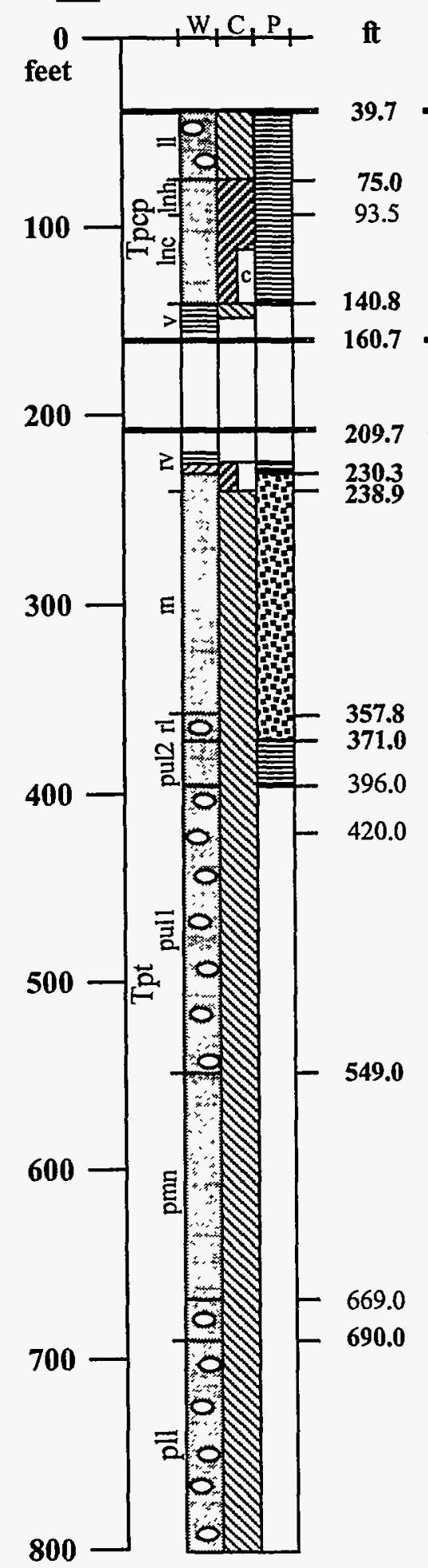

\section{Alluvium (QTac)}

Tiva Canyon Tuff (Tpc) - (Phenocrysts of san and hbl)

Crystal-poor lower lithophysal zone: Lithophysae are 2 to 5 percent of rock, and light gray spots and rims form 5 to 10 percent. Cavities less than $2 \mathrm{~mm}$ at $60.7-75.0$

Crystal-poor lower nonlithophysal zone:

hackly subzone $(\operatorname{lnh})(75.0$ - 93.5) - hackly fractures on broken surfaces

columnar subzone (lnc) (93.5 - 140.8) - hackly fractures not well developed, closely spaced joints at 93.5 , top of clay-filled pumice pseudomorphs at 112.0

Crystal-poor vitric zone: partially welded and devitrified with less than $2 \mathrm{~mm}$ vapor-phase filled cavities $(140.8-153.9)$, vitric nonwelded $(157.5$ - 160.8)

Bedded tuffs - Six bedded deposits, each with orange top. Includes Yucca Mountain

\section{Topopah Spring Tuff (Tpt) -}

7 Crystal-rich vitric zone: post-Topopah Spring Tuff bedded tuff (188.8 - 209.7) with paleosol (?); $1 \mathrm{~cm}$-thick lithic-rich fallout tephra (209.7); nonwelded and moderately welded vitric subzones; vitrophyre subzone (230.3 - 238.9); phenocrysts of feld, bio, minor hbl and cpx

Crystal-rich nonlithophysal zone:

Phenocrysts of feld, bio, with minor hbl and cpx

Minor amounts of brown pumice down to 413 .

Crystal-rich lithophysal zone (rl) (357.8 - 371.0); phenocrysts of feld, bio, with minor hbl and cpx.

Crystal-poor upper lithophysal zone: phenocrysts of feld and bio

lithophysae-poor subzone (pul2) $(371.0$ - 396.0)

lithophysal zone (pul1) (396.0 - 549.0)

(In previously published lithologic logs, the crystal-rich and crystal-poor lithophysal zones were probably logged as a single unit.)

Increase in size and amount of brown pumice to 455 , at 420.0 a brown pumice is $12 \mathrm{~cm}$ along core axis.

Lithophysae are approximately $35 \times 45 \mathrm{~cm}$, have $5 \mathrm{~mm}$-wide light grey rims, and hackly fracture is moderately well developed.

Crystal-poor middle nonlithophysal zone:

conchoidal breakage is typical along high-angle fractures: ;

vapor-phase minerals fill some fractures

transition subzone with rare lithophysae and change from conchoidal high-angle fractures to small en echelon hackly fractures $(669.0-690.0)$

Crystal-poor lower lithophysal zone:

lithophysae are approximately $15 \times 60 \mathrm{~cm}$, have $15 \mathrm{~mm}$-wide light grey rims, and hackly fracture is moderately well-developed.

high-angle hackly fractures, many en echelon (887.0 - 1054.6)

38 Summary of Lithologic Logging of New and Existing Boreholes at Yucca Mountain, Nevada, August 1993 to February 1994 
Drill hole : UE-25 UZ\#16

Data Tracking Number: GS931208314211.047

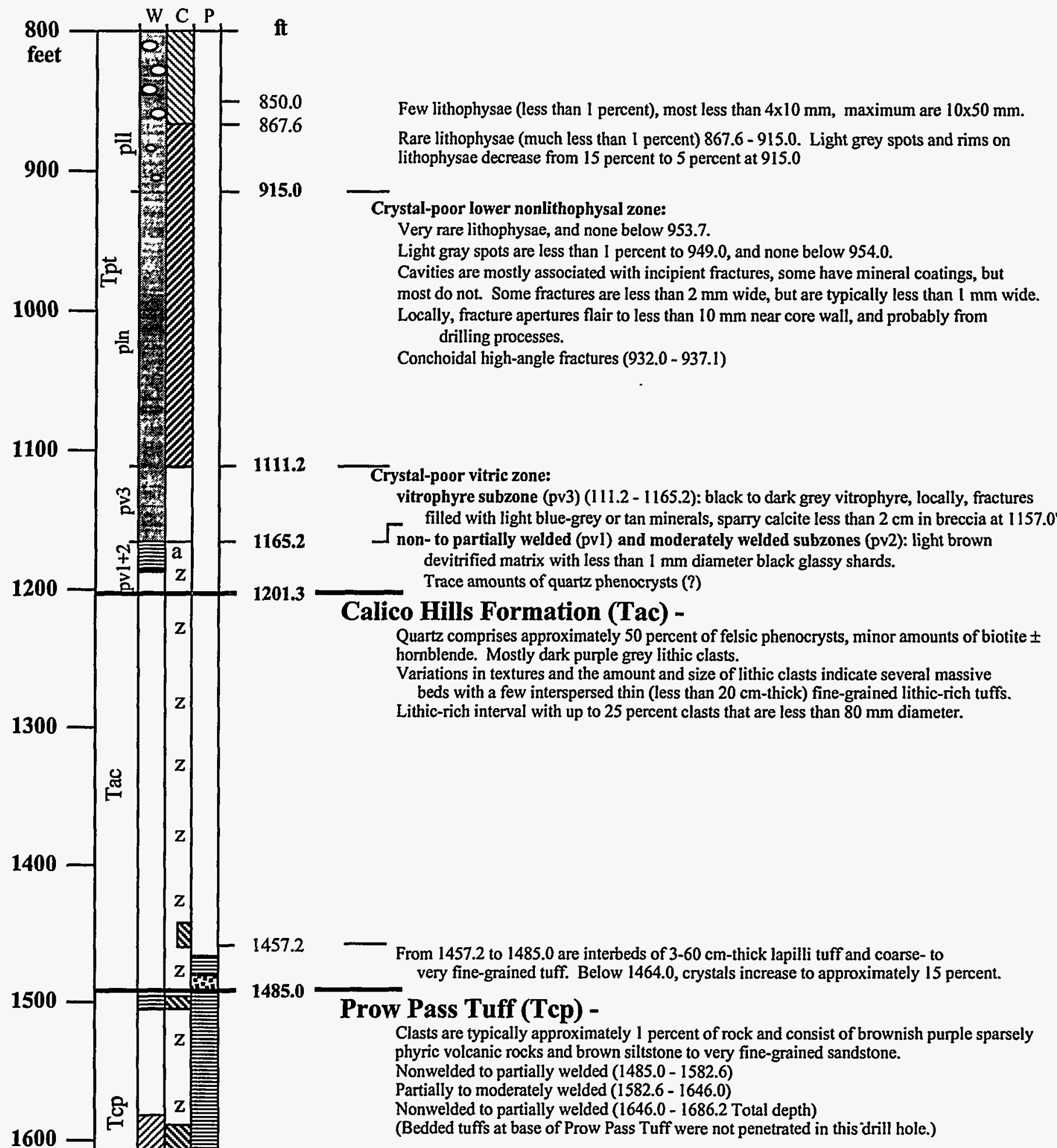

(Bedded tuffs at base of Prow Pass Tuff were not penetrated in this'drill hole.)

1686.2 Total Depth 